\title{
Unknown letters of the Metropolitan of Kiev Hipacy Pociej, an important source on the beginnings of the Brest Union
}

The Uniate Metropolitan of Kiev, Hipacy (his secular name being Adam) Pociej (1541-1613) was among the most interesting, but at the same time most controversial personnages of the Commonwealth at the turn of the sixteenth and seventeenth centuries. ${ }^{1}$ This was because of his involvement in a fraught with consequences internal conflicts of the Polish-Lithuanian state, and namely the argument between the supporters and opponent of the Brest Union (1595/96), that took place on the religious (in a polemical way) as well as political and legal planes. The conflict - as each one with underlying religious issues - stirred emotions of the nobility, particularly in eastern regions of the Commonwealth, and occasionally it turned violent. Also Hipacy Pociej contributed to this,

1 No exhaustive biography of Pociej has been written to date, although there are several publications devoted to him; majority of them date from the nineteenth and early twentieth centuries: N. Tripolskij, 'Uniatskij mitropolit Ipatij Potiej i jego propowiedniczeskaja diejatelnost”, Trudy kiewskoj duchownoj akademii, 1877, no. 10, pp. 123-81; O. Lewickij, 'Ipatij Potiej, kiewskij uniatskij mitropolit', Pamiatniki russkoj stariny w Zapadnych gubiernijach, 8, 1885, pp. 342-74; M. Czubatij, Mitropolit Ipatij Potij-apostot cerkovnoj jednosti, Lvov, 1914; Juwiliejna kniga w 300-rokowini smierti mitr. I. Potija, Lvov, 1914 (a lengthy biographical note is found on pp. 31-133, by Sawickij); A. Piekar, 'Ipatij Potij - prowisnik zjedinennia', Analecta Ordinis Sancti Basili Magni, 15, 1996, pp. 145-246. Recently, a popular work on Pociej has been published: S.A. Padokszyn, Ipacij Pacej. Carkouny dzejacz, myslicel, pismiennik na pieratomie kulturna-histarycznych epoch, Minsk, 2001. Cf. the entry J. Dzięgielewski, Pociej Hipacy, in Polski Stownik Biograficzny, vol. 27, Wrocław, 1982-83, pp. 29-34. 
through his attitude towards objectors to the Union. He was doubtless a man of strong personality and inexhaustible energy, which was particularly clearly visible in his efforts to support the Union of Brest. In the light of our knowledge of that time, he can be considered as one of the most important architects of the Union. Today, it is hard to imagine the Uniate church in its beginnings, without his activity.

It should be remembered that Pociej renounced the senatorial office of the Castellan of Brest, assuming in 1593 the less prestigious (considering the status of Orthodox bishops in the Commonwealth) position of the bishop of the Volodymyr-Brest eparchy. It was only then, that the talks on the unification of Kiev metropolia (including members of the Orthodox church from the whole Commonwealth) with the Roman Catholic church intensified. However, it was only after the Union of Brest had been formed and it turned out that the majority of Orthodox Christians opposes it, that Pociej fully displayed his tenacity and belligerent nature. With the help of king Sigismund III and through influential Catholic magnates, particularly the Chancellor of Lithuania Lew Sapieha, he fought ruthlessly against the anti-Uniate opposition. The leader of the opposition was at that time the wealthiest man of the Commonwealth, aged voivode of Kiev Konstanty Wasyl Ostrogski (ca. 1524/25-1608). Among the six bishops who supported the submission of the Kiev metropolia to the Pope,${ }^{2}$ it was Pociej who displayed the indefatigable energy in seeking the support for the Uniate church. His stand became even more clear when he took over in 1599 the post of Metropolitan ${ }^{3}$ from Michat Rahoza (who, apparently, was not completely convinced that he should support the union with the Roman church). ${ }^{4}$ As the head of the Uniate church, Pociej helped it to survive in such difficult moments as Zebrzydowski Rebellion, when non-Catholics (Orthodox Christians together with

2 Only two bishops opposed the Union of Brest at the council in Brześć Litewski, in October 1596: the bishop of Lvov (Gedeon Bałaban, who supported initially the plans for unification) and bishop of Przemyśl (Michał Kopysteński).

3 Cf. Akty otnosjaszczesja k istorii zapadnoj Rossji, sobrannyje i izdannyje Archeograficzeskoju Kommissijeju (hereinafter: $A Z R$ ), vol. 4, Sankt Petersburg, 1858, no. 143, pp. 198-99. The nomination has been officially confirmed by Rome in 1600 . Moreover, the Pope granted Pociej a dispensation, allowing him to retain (mainly on economic reasons) the Volodymyr-Brest eparchy, which he held until his death in 1613. See Monumenta Ucrainae historica (hereinafter: $M U H$ ), vol. 1, ed. by A. Septyckyj, Rome, 1964, no. 271-77, pp. 187-91.

4 Concerning his moral dillemas over the union, see: T. Kempa, 'Metropolita Michał Rahoza a unia brzeska', Klio, 2, 2002, pp. 48-100. 
Protestants) demanded firmly the union to be cancelled. ${ }^{5}$ On the other hand, the religious activity of Pociej contributed to the intensification of the conflict between Uniates and Orthodox Christians. For the objectors to the Union, he became a symbol of the betrayal of Orthodoxy, as did the Lutsko-Ostrog bishop Cyryl Terlecki. In the context described above, researchers into the early history of the Union of Brest have noticed the value of the Pociej's correspondence for the history of the Uniate church and of inter-confessionary relationship in the Commonwealth at the turn of the sixteenth and seventeenth centuries. Thus, the majority of the bishop's letters has been already published. This is true for over twenty Latin and Italian letters sent by Pociej to subsequent Popes (Clement VIII, Paul V), cardinals of the Roman Curia (Petro Aldobrandino, Camillo Borghese) or papal nuncios to the Commonwealth (Francisco Simonetta). ${ }^{6}$ Well known are also several extremely interesting letters written by Pociej in Ruthenian to Konstanty Ostrogski and to the Kiev Metropolitan Michał Rahozy when preparations were being made for the Union of Brest. ${ }^{7}$ These sources are of crucial importance for our understanding the genesis of the Union. Moreover, letters sent by Pociej (as the Metropolitan) to bishops and the faithful of the Greek Orthodox church also have been published. ${ }^{8}$ Also numerous letters written in

5 More on this subject, see: idem, 'Prawosławni wobec rokoszu Zebrzydowskiego', in Homo doctus in se semper divitias habet. Ksiega pamiatkowa ofiarowana Profesorowi Januszowi Mattkowi z okazji siedemdziesiatej rocznicy urodzin i pięćdziesiątej rocznicy rozpoczęcia pracy naukowej, ed. by W. Polak, Toruń, 2008, pp. 263-83.

6 Published in: Litterae episcoporum historiam Ucrainae illustrantes, vol. 1 (1600-1640), ed. by A. Welykyj, Rome, 1972, passim, and in $M U H$, vol. 1, passim.

7 Published in Documenta Unionis Berestensis eiusque auctorum (1590-1600), ed. by A. Welykyj (hereinafter: $D U B$ ), Rome, 1970, nos. 21, 25, 31, 33, 36, 43, 74, pp. 41-43, 46-47, 51-55, 57-58, 75-78, 123-24; $A Z R$, vol. 4, nos. 56, 59, 63, 66, 70, pp. 81-82, 85-86, 88-90, 92-93, 97-99. See also: H. Pociej, Antirresis abo apologija przeciwko Krzysztofowi Philaletowi..., ed. by J. Byliński and J. Długosz, Wrocław, 1997, pp. 221-37 (the famous 'polemical' letter of Pociej to Konstanty Ostrogski, dated June 3, 1598). 8 I.e. the letters of H. Pociej: to the bishop of Lvov Gedeon Bałaban and to the clergymen of the Lvov eparchy in Lvov - dated May 22, 1604 (in Borot'ba Piwdienno-Zachidnoji Rusi i Ukrajini proty jekspansiji Watikanu ta uniji (X-poczatok XVII st.). Zbirnik dokumientiw i materialiw, Kiev, 1988, no. 129, pp. 180-81); to the bishop of Lvov (Bałaban's successor) Jeremiasz Tyssarowski - dated August 27, 1608 (in $A Z R$, vol. 4, no. 176, pp. 263-64. Latin copy of the letter has been published in Litterae episcoporum..., op. cit., vol. 1, no. 31, pp. 41-43, and in M. Harasiewicz, Annales Ecclesiae Ruthenae, Lvov, 1862, pp. 443-45); to Iwan Parfienowicz, deputy Metropolinan of Vilnius - dated September 24, 1599 (in $A Z R$, vol. 4, no. 142, pp. 196-98); 
Polish - the language which he spoke usually - have appeared in print. The majority of them was addressed to the Chancellor Lew Sapieha. ${ }^{9}$ The Uniate church, as well as the Kiev Metropolitan himself owe a lot to the magnate. ${ }^{10}$ Several Pociej's letters to the voivode of Troki (and that of Vilnius since 1604) Mikołaj Krzysztof Radziwiłł 'Sierotka' are preserved (five of them have been already published). ${ }^{11}$ Moreover, five

to Orthodox citizens of Słuck - dated May 29 and June 3, 1600 (in $A Z R$, vol. 4, no. 153, pp. 239-40); to Vilnius mayors (tawica ruska), January 2, 1609 (in $A Z R$, vol. 4, no. 178, pp. 312-13); to the authorities of Vilnius - dated September 18, 1608 and December 24, 1608 (in Archieograficzeskij sbornik dokumientow otnosjaszczesja k istorii siewierozapadnoj Rusi (hereinafter: $A S$ ), vol. 6, Vilnius, 1869, nos. 58 and 60, pp. 112-15, 121-22); to Grigorij Chorelski and his wife Hanna - dated March 1, 1603 (in O. Ogloblin, 'Nieopublikowanij list mitropolita Ipatija Potija z 1603 r.', Analecta Ordinis S. Basili Magni, 2, 1956, pp. 470-72). See also Pociej's letter (in Polish) to coadiutor of the Kiev Metropolia Józefat Welamin Rutski, dated June 17, 1611 (in: $A S$, vol. 6, no. 79, pp. 172-74). It should be added that both 'Ruthenian' and 'Polish' letters written by Pociej to persons originating from the 'circle of the Eastern church' are dated according to Julian calendar.

9 Nineteen letters to Lew Sapieha have been published in: Archiwum domu Sapiehów, vol. 1 (hereinafter: $A D S$ ), ed. by A. Prochaska, Lvov, 1892. The letters are published also in Ukrainian (cf. Ju. Mycyk, 'Listy Ipatija Potija do Lwa Sapihy', Katolic'kij szczoricznyk, 2000 (2003), pp. 73-204). Moreover, two letters to Sapieha (in Kiev Archive) have been published by an eminent historian of the Union of Brest, Leonid Tymoszenko (cf. idem, 'Dwa listy Ipatija Potija do Lewa Sapiehy', Kijiws'ka Starowina, 2002, no. 1/343, pp. 103-13). Two other Pociej’s letters are published by Mychajło Wozniak, as is a Metropolitan's letter to the Słonim nobility (dated February 28, 1607). See: idem, 'Tri stattiejki zpolemicznoho pismienstwa', Zapysky Naukowoho Towarystwa imieni Szewczenka, 99, 1930, pp. 43-50. Another Pociej's letter to Sapieha (dated 1609) is published in $A S$, vol. 6, no. 77, pp. 161-65.

10 For Sapieha's activity supporting te Uniate church, see T. Kempa, 'Kanclerz Lew Sapieha a Kościót unicki', in Sapiehowie epoki Kodnia i Krasiczyna, ed. by K. Stępnik, Lublin, 2007, pp. 27-42.

11 Two letters (dated February 12, 1593 and August 23, 1599) are published in $D U B$, nos. 6 and 326, pp. 14-16, 483-86 (earlier published by B. Barvinskij, 'Dwa listy mitr. Ipatija Potija', Analecta Ordinis S. Basili Magni, 2, 1956, pp. 466-69); two other letters (dated June 11 and 24, 1595): T. Kempa, 'Nieznane listy dotyczące genezy unii brzeskiej (1595/1596)', Odrodzenie i Reformacja w Polsce, 44, 2000, pp. 112-13. All of them are kept in Czartoryski Library in Cracow. One of the letters, dated September 9, 1600 (it was destroyed by Germans after the Warsaw Uprising in 1944, together with other manuscripts that had been regained from Leningrad as a result of the Treaty of Riga), is published in P. Żukowicz, Siejmowaja borba prawoslawnago zapadnorusskago dworjanstwa s cerkownoj uniej (do 1609 r.), Sankt Petersburg, 1901, appendices, no. 6, p. 592. 
Metropolitan's letters to the superior of the Ruthenian province of the Dominican Order, Antoni of Przemyśl, have been recently published by Natalia Sinkiewicz, ${ }^{12}$, and two others, addressed to the same person, were available earlier. ${ }^{13}$ Finally, several Pociej's letters to magnates and wealthy nobles also appeared in print. ${ }^{14}$

The tellers of the Uniate hierarch are noteworthy not only for their contents, but also for the vivid language of their author. Pociej spoke Polish easily and he had a rich vocabulary, as evidenced by his autographs. Due to the nature of its content, as well as the temperament of its author, the correspondence contains a good deal of metaphors, similes and emotional sentences.

It is because of the fact that the letters were often written in the heat of the moment, numerous issues are exaggerated. Obviously, Pociej acted intentionally - usually to discredit his opponents and to interest his audience in the fate of Uniates. Of the Union of Brest, he spoke always reverently, using such phrases as 'the sacred union', 'the sacred unity' or 'the sacred concord', and he tried to present himself as a man so concerned with the thorny development of the Union that his 'eyes never go dry from crying' ('nigdy od płaczu oczy [...] nie osychają'). ${ }^{15} \mathrm{He}$ compared the function of the head of the Uniate church to an 'oppresive bondage', ${ }^{16}$ because of the responsibility and dangers it involved. ${ }^{17} \mathrm{I}$ have

12 Cf. N. Sinkiewicz, 'Nieopublikowani listy Ipatija Potija - szcze odno dżerelo do istoriji Kijiwskoji mitropoliji poczatku XVII st.', Eawrskij Almanach, 2010. All these letters are found in a copy-book kept in the National Library in Warsaw (sign. II 5698). 13 One of these letters is dated January 14, 1601, the other without date (written in 1603) published in Borot'ba Piwdienno-Zachidnoji Rusi..., op. cit., nos. 123 and 128, pp. 171-73, 178-80; $A Z R$, vol. 4, pp. 209-10; $M U H$, vol. 1, no. 290, pp. 197-99. 14 Cf. an undated letter (of 1609) to [Hrehory] Tryzna, in $A S$, vol. 6, no. 78, pp. 165-71 and an epistle to Krzysztof Radziwiłł 'Piorun' dated February 25 1594, in S. Gołubiew, Kiewskij mitropolit Pietr Mogita i jego spodwiżniki, vol. 1, Kiev, 1883, Appendix 10, pp. 36-37.

15 Cf. a letter of H. Pociej to Mikołaj Krzysztof Radziwiłł ('Sierotka') sent on August 23, 1599 from Volohymyr, in DUB, no. 326, pp. 483-85.

16 H. Pociej to Mikołaj Krzysztof Radziwiłł 'Sierotka', on June 1, 1601, from Vilnius, Library of the Polish Academy of Sciences in Kórnik (hereinafter: BKórn.), 1539, no. 64, see the letter no. 2.

17 Pociej was aware of being the main target of the attacks of the opponents to the Union. In a letter to Lew Sapieha (September 9, 162), he wrote: "everything at once descended on my poor head and I can say after Paul the Apostle: I am endangered by my own people, endangered in a city, endangered among my false brethren at work and in trouble" ("wszytko się razem na moją biedną głowę obaliło, że też mogę po 
presented a detailed analysis of the Pociej's correspondence in Polish on another occasion. ${ }^{18}$ The above general remarks are intended only as an introduction to the text published here.

Eleven letters, never published before, are kept in the Library of the Polish Academy of Sciences in Kórnik, ${ }^{19}$ the Czartoryski Library in Cracow and in the Central National Historical Archive (Centralnyj dierżawnyj istoricznyj archiw Ukrajiny) in Kiev. These are addressed to Sigismund $\mathrm{III}^{20}$ and two Roman-Catholic magnates who supported the Union of Brest: Lew Sapieha and Mikołaj Krzysztof Radziwiłł 'Sierotka'. Besides, the appendix contains a letter written to Sigismund III by bishop Cyryl Terlecki - apart from Pociej, the main supporter of the unification of the Kiev metropolia with Rome, among the Orthodox bishops. It is the only known letter written in Polish by Terlecki alone (there are a few letters that he co-authored with Pociej).

In the letters published herewith, Pociej brings up issues that were of importance for the Uniate church. In the first, which he wrote shortly after he became the Kiev Metropolitan, he points out problems caused to him by the Orthodox. First he complains about the activity of the Lvov bishop Gedeon Bałaban, who, in the face of the majority of Ruthenian bishops having approved the union, tried to be a shepherd for all adherents of the Orthodoxy in the Commonwealth. Thus, he ordained priests also outside the Lvov eparchy. Naturally, Pociej did not accept such actions of Bałaban, accusing him of meddling in his (as the bishop of the Volodymyr-Brest eparchy and as the Metropolitan) territory of

części mówić z Pawłem apostołem: jestem w niebezpieczności od swego narodu, w niebezpieczeństwach w mieście, w niebezpieczeństwach między fałszywą bracią w pracy i w kłopocie"), $A D S$, no. 409, p. 342). In 1609, there was an attempt on the Metropolitan's life. Pociej survived, but he lost two fingers. I discuss the subject in Wydarzenia wileńskie z lat 1608-1609 - konflikt duchowieństwa obrzadku greckiego z metropolita kijowskim Hipacym Pociejem (forthcoming). Cf. also P. Żukowicz, 'Posledniaja borba duchowienstwa mitropolicziej jeparchii s Potiejem i uniej (1609-11)', Christianskoje Cztienie, 212, 1901, p. 374.

18 T. Kempa, 'Metropolita kijowski Hipacy Pociej w świetle swojej korespondencji', in Epistolografia w dawnej Rzeczypospolitej, vol. 1, Cracow, 2010.

19 It was already Leonid Tymoszenko, who appreciated the significance of Pociej's letters to Sigismund III (in the Kórnik Library). See idem, 'Niewidomi listy Ipatija Potija do Żigimonta III', in Istorija religij $w$ Ukrajini. Praci XI-ji miżnarodnoji naukowoji konferencji (Lwiw, 16-19 trawnja 2001 roku), vol. 1, Lvov, 2001, pp. 438-43.

20 I know only one letter of the Metropolitan to Sigismund III, that has been published to date. See: 'H. Pociej do Zygmunta III 10 IV 1609', in $A S$, vol. 6, no. 63, pp. 128-29. 
jurisdiction. The head of the Uniate church emphasised that the Lvov bishop did it despite of a royal letter banning him from such actions.

The main source of concern was for Pociej at that time the situation in Vilnius. He was aware that when all members of the Greek Orthodox church in the capital of the Grand Duchy will submit to the union, it will be accepted by the whole Lithuania, or at least by all cities subordinated directly to the king. His view was shared by the Chancellor Lew Sapieha, who firmly supported the union in Vilnius (and he did it using not only legal means). ${ }^{21}$ The supporters of the union tried to take control of all churches in the city, as Pociej knew that when there will be no churches controlled by opponents to the union, the citizens of Vilnius will be forced to attend the Uniate ones. The majority of churches was taken by Uniates when the Metropolitan Rahoza was still alive, the rest - in the first months of Pociej's office. The only exception was the church of the Holy Spirit, the construction of which has been started by the Orthodox in 1596, as if expecting the worse. It was not only Orthodox citizens of Vilnius who looked after it, but also the nobility of the Greek rite. It was to that church, that the Orthodox brotherhood moved from the church of the Holy Trinity. The Uniate hierarchs, even supported by Sigismund III, were unable to stop the construction of the Holy Spirit church, as it was built on private ground, donated by Wołłowicz sisters specifically for this purpose. ${ }^{22}$ The Brotherhood of the Holy Spirit became the main opponent of Pociej, not only in Vilnius itself. It was the most important intellectual centre of the Orthodoxy in Lithuania, and now and then in the whole Commonwealth. ${ }^{23}$ In a letter sent from the 'metropol court',

21 For a further discussion, see T. Kempa, 'Współpraca prawosławnych i ewangelików na terenie Wilna w latach 1596-1603', in Silva rerum nova. Sztudyi u honar 70-goddzja Gieorgija Ja. Galienczanki, Vilnius and Miensci, 2009, pp. 155-61; idem, Wobec kontrreformacji. Protestanci i prawostawni w obronie swobód wyznaniowych $w$ Rzeczypospolitej w końcu XVI i w pierwszej potowie XVII wieku, Toruń, 2007, pp. 133 ff.

22 Both were married to influential Lithuanian senators: Dorota Wołłowiczówna to the Smoleńsk voivode Jan Abramowicz, and Fedora - to Brest voivode Krzysztof Zenowicz. It should be remembered that both Abramowicz and Zenowicz were Calvinists. The former actively supported the cooperation between Protestants and Orthodoxes. Kempa, Wobec kontrreformacji..., op. cit., pp. 134-35, 137.

23 For a broader discussion on the role of the Holy Spirit Brotherhood as a bastion of Orthodoxy in the Grand Duchy at the turn of the sixteenth and seventeenth centuries, see T. Kempa, 'Wileńskie bractwo św. Ducha jako centrum obrony prawosławia w Wielkim Księstwie Litewskim w końcu XVI i w pierwszej połowie XVII wieku', Biatoruskie Zeszyty Historyczne, 21, 2004, pp. 47-69. 
Pociej mentions that bishop Bałaban ordained two priests specifically for the brotherhood. ${ }^{24} \mathrm{He}$ emphasised that the action infringed his jurisdiction and the Canon Law. He requests Sapieha's intervention, 'as (they) feel a great respect for Your Highness' ('gdyż z wielkim postrachem na Wasz Mości samego barzo się oglądają').

Noteworthy is how describes Pociej the dis-Uniates. He used such contemptuous and blunt epithets as 'the cursed schism' or 'scoundrels' den' (when talking of the Vilnius brotherhood). It was Pociej himself who coined the term 'naliwajkowska (nalewajkowska) orda' (Nalewajko's horde). ${ }^{25}$ The horde in question was, obviously, a reference to Tatars - the most formidable enemies of Ruthenian lands of the Crown, and Nalewajko was the leader of a Cossack rebellion in1595-1596. Pociej used the term consistently, sometimes in an abbreviated form 'naliwajkowie'. It must be said that the term has been commonly accepted in circles hostile to dis-Uniates. ${ }^{26}$ Pociej tried different ways to discredit the Orthodoxes. Noteworthy, in the letter analysed here ('from the metropol court') he accuses them for the betrayal of the king and of the Commonwealth saying that they would gladly accept a victory of Michael the Brave, the Orthodox prince of Wallachia (which was at war with the Commonwealth at that time), 'over Romans'. When embarrassing the dis-Uniates in his letters, he accuses the Catholics of failing to support enough the Union of Brest. He complains about 'a great downfall of the church of God and lambs [i.e. the Uniates- T.K.] atrociously disappointed'. In a letter to Radziwiłł 'Sierotka', dated June 1, 1601, he mentions 'the calamity and downfall of our church'. Moreover, Pociej points out the inconsistency in penalising Orthodoxes: 'oto i teraz pop wyklęty od antecessora mego i od Jego Królewskiej Mości banniowany Wasilej tu mieszka' ('now, the

24 Karp Łazarowicz and Hrehory Żdanowicz. Thanks to efforts of Pociej and Sapieha, the king banished them, after both had been banished by the Metropolitan court on July 20,1601. The Tribunal of Lithuania, at that time dominated by Orthodoxes and Protestants, objected to that sentence. Despite of having been exiled, both priests stayed in Vilnius for next few years. See Kempa, 'Współpraca prawosławnych i ewangelików...', op. cit., pp. 160-61.

25 See, e.g. $A D S$, no. 408, p. 339; no. 538, pp. 438-40; no. 541, pp. 442-43; no. 561, p. 458; no. 583, p. 475. Occasionally, Pociej used even more rude epithets in relation to Orthodoxes, calling them, e.g. 'mindless animals' (cf. the letter of H. Pociej to Lew Sapieha, dated September 9, 1602, sent from Biskupice, in $A D S$, no. 409, p. 341).

26 It was used also by other Uniate hierarchs (although not as consistently as Pociej did), e.g. the Metropolitan Józef Welamin Rutski, and Catholic laypersons: Lew Sapieha or the Chancellor Stanisław Albrycht Radziwiłł. 
priest excommunicated by my antecessor and banished by His Majesty, Wasiliej, lives here').

In his letters to Lew Sapieha and to Mikołaj Krzystof Radziwiłł 'Sierotka', Pociej took the liberty of harsher criticising the Roman Catholics, while in the letters to Sigismund III, his criticism is more lenient. When writing to the Lithuanian magnates, he resorts actually to blackmail: without having sufficient help of Roman Catholics, he will leave the metropolia to be replaced by someone younger, 'who would manage these works and troubles' ('który by tym pracam i kłopotam sprostał' - in the Pociej's letter 'from the metropol court'). Actually, he threatened to resign the Metropolitan office also in following years. ${ }^{27}$

In the letter to Radziwiłł 'Sierotka' dated June 1, 1601, Pociej refers again to the usurpation of the control over his eparchies by Bałaban which was an important matter for him. It is evident that the issue of priests being ordained by Bałaban for the Vilnius brotherhood has not been solved yet in the way as he intended. Additionally, Pociej complains that the priests - to legitimise their actions and to strike at the Metropolitan's jurisdiction - brought with them to Vilnius 'charters with huge seals, set with pearls' ('przywileja z pieczęciami zawiesistemi perły osadzonemi'), and he adds sarcastically that he does 'not know whether they are issued by the Constantinopolitan or by the Volhynian patriarch' ('nie wiem, czy patriarchy konstantynopolskiego, czyli wołyńskiego są'). As the 'Volhynian patriarch' describes Pociej sneeringly the leader of the anti-Uniate camp - the voivode of Kiev Konstanty Wasyl Ostrogski. Noteworthy is also a request of the Metropolitan who asks 'Sierotka' to send him 'a representation of the Holy Sepulchre'. This indicates that the head of the Uniate church did not give up various forms of the religious propaganda, to win hearts and minds of the faithful through visual media. The Metropolitan requested also from Radziwiłł a copy of 'Peregrynacja do ziemi świętej', which has been completed, but not published yet. ${ }^{28}$

27 This was, e.g., during an argument between the Orthodoxes and Uniates over the control of the wealthiest and most important monastery in the Commonwealth - Pechersk Lavra; see H. Pociej to Lew Sapieha, April 5, 1603, in ADS, no. 437, pp. 366-68. On the conflict over the monastery, see T. Kempa, 'Rywalizacja o Ławrę Peczerską w Kijowie między prawosławnymi a unitami w końcu XVI i na początku XVII wieku', Przeglad Wschodni, 8, 2003, 4 (32), pp. 831-78.

28 It appeared in print only a few months later, in 1601 in Braniewo. Cf. S. Alexandrowicz, 'Peregrynacja do Ziemi Świętej księcia Radziwiłła Sierotki. Czas powstania rękopisu', in Ars Historica. Prace z dziejów powszechnych i Polski, Poznań, 1976, pp. 
In another letter (to 'Sierotka', dated September 30, 1601) there are - exceptionally - no references to the Union of Brest. It appears that Pociej intended to participate in an important event (which he 'never saw before' in Nieśwież, where also the Papal nuncio to the Commonwealth, Claudio Rangini was to be present. The event in question was most probably, the first Mass to be celebrated in the newly built church of Saint Catherine at the Observant Monastery in the main residence of 'Sierotka' Radziwiłł. Perhaps, the nuncio intended to consecrate the monastery's buildings on the same occasion..$^{29}$ Moreover, we learn from the same letter of heavy losses suffered by the estates of the Volodymyr-Brest eparchy and the Kiev metropolia as a result of poor harvests. His letters indicate that the famine, which resulted from that situation, was considered as a well-deserved punishment for sins by the Uniate hierarch.

In the first of his letters written to the king (dated April 22, 1602), Pociej tried to persuade Sigismund III to support more vigorously the interests of the Uniate church and - above all - to fight its opponents. The Metropolitan argued that the lack of a firm royal response to the activity of the enemies of the union enfeebled the king's authority. ${ }^{30}$ The main thread of the letter is the ascension to the patriarchal throne in Constantinople of Cyril Lucaris, for whom Pociej had great hopes (and who visited the Commonwealth several times before). Actually, Lucaris became Patriarch of Alexandria at that time. ${ }^{31}$ Pociej hoped - in vain, as

593-94; T. Kempa, Mikotaj Krzysztof Radziwitt Sierotka (1549-1616), wojewoda wileński, Warsaw, 2000, pp. 124-26. The most recent Polish edition: M.K. Radziwiłł 'Sierotka', Podróż do Ziemi Świętej, Syrii i Egiptu 1582-1584, ed. by L. Kukulski, Warsaw, 1962. 29 According to some accounts, the first Mass in the monastery church was celebrated on November 15, 1601. Cf. Kempa, Mikotaj Krzysztof Radziwitt..., op. cit., p. 165. On the Observant Monastery and Saint Catherine church in Nieśwież, see also T. Bernatowicz, Miles Christianus et peregrinus. Fundacje Mikotaja Krzysztofa Radziwitta 'Sierotki' w ordynacji nieświeskiej, Warsaw, 1998, pp. 67-70.

30 This argument was used by Pociej also in his other letters. See, e.g. H. Pociej to Lew Sapieha, December 2, 1605, in $A D S$, no. 583, pp. 475-76.

31 It was only in 1620 that he became the Ecumenical Patriarch of Constantinople; he remained in office, intermittently, until his death (he was executed on the sultan's order) in 1638. In 2009, he has been proclaimed a saint by the Patriarchate of Alexandria and other autocephalous Orthodox churches, including the Polish church. This was a subject of a heated debate, because Lucaris is considered by numerous theologians and historians as a crypto-Calvinist. Such was also the spirit of an Orthodox Credo written by him and first published in Geneva in 1629 (it was only in 1633 that it appeared in Greek). 
it turned out - that the new Patriarch will at least 'pacify' the opponents of the Union of Brest, and his hopes were grounded on - among others - a letter sent by the Greek priest, upon leaving the Commonwealth, to the Latin Archbishop of Lvov, Jan Dymitr Solikowski (January 24, 1601). Lucaris, who acted at that time as an exarch and envoy of Meletius Pegas, Patriarch of Alexandria declared himself to be a supporter of the unity with the Roman church, although he considered any union between the Orthodox and Catholic churches as impossible because of the political situation (the conflict between Turkey, controlling the ancient patriarchates, and Christian states in Europe). ${ }^{32}$ Some historians deem that letter to be a forgery, because it has been first published (in Polish translation) by Piotr Skarga in Na Threny i lament Theopila Orthologa do Rusi greckiego nabożeństwa przestroga (Vilnius 1610). Pociej's epistle, however, which is published here, dissipates any doubts. It should be added that, during Lucaris' stay in the Commonwealth, the Uniate Metropolitan insisted on the king arresting the exarch or expelling him from the country. ${ }^{33}$ Pociej suspected that the Greek priest came to the Commonwealth to prevent the Union of Brest and to bolster a political alliance between the Orthodox and Protestant churches that had functioned since several years (in Sejm and sejmiks, among others) and was a source of trouble for the hierarch. ${ }^{34}$ After Lucaris had contacted the bishop Solikowski and Mikołaj Krzysztof Radziwiłł 'Sierotka' (in December 1600 in Nieśwież), ${ }^{35}$ however, Pociej changed his opinion on the Greek priest. This is why he asked the king to send a letter to the new patriarch (or to have Solikowski

32 The original, Latin version of the letter has been published in: Litterae episcoporum..., op. cit., vol. 1, no. 6, pp. 7-11.

33 See H. Pociej to Mikołaj Krzysztof Radziwiłł 'Sierotka' on September 9, 1600, in Żukowicz, Siejmowaja borba..., op. cit., Appendix 6, p. 592. Cf. a fragment of Pociej's letter to 'Sierotka', dated November 30, 1600, ibid. See also: a letter of Sigismund III to C. Lucaryia, [s.d.] (ca. the middle of 1600), sent from Warsaw, Central Archives of Historical Records in Warsaw (AGAD), Radziwiłł Archive, Rękopisy Biblioteczne, V-92, 1. 271; Konstanty Ostrogski to Sigismund III, July 28, 1600, in Documente privitoare la istoria Romanilor, supl. II, vol. 1 (1510-1600), ed. by J. Bogdan, Bucarest, 1893, no. 335, p. 628.

34 More on the activity of Cyril Lucaris in the Commonwealth: T. Kempa, 'Wizyty protosyngla Cyryla Lukarysa w Rzeczypospolitej', in The Orthodox Church in the Balkans and Poland. Connections and Common Tradition, ed. by A. Mironowicz, U. Pawluczuk, and W. Walczak, Biatystok, 2007, pp. 87-103.

35 T. Kempa, 'Mikołaj Krzysztof Radziwiłł “Sierotka” a unia brzeska', Czasy Nowożytne, 1997, 2, pp. 54-56. 
do this), to enhance his pro-union sympathies. It is not known, whether such letter has ever been sent. Anyway, during his next few years as the Patriarch of Alexandria, Lucaris treated Catholics kindly, and, in 1608, he sent a letter to the Pope Paul V, acknowledging him as the head of the universal church. ${ }^{36}$

In several subsequent letters to Sigismund III, Pociej discussed a problem of an exceptional importance for the Uniate church - that of appointing successors to deceased bishops, as well as clergymen of lower ranks in churches and monasteries dependent on the king. The letters indicate that such nominations occurred usually on the recommendation of the Metropolitan himself, and occasionally upon the request of other persons (Lew Sapieha, above all). In his letters dated March 2 and April 25, 1604, solicited (successfully) for Iwan (monastic name: Arseniusz) Andrzejowski (Andrzejewski) to be nominated as the bishop of Chełm. An important factor was for the Metropolitan not only the noble background of Andrzejewski (and the fact that he was supported by the Ruthenian nobility), but - more than other things - his allegiance to the union, ${ }^{37}$ as several clergymen appointed by Sigismund III had turned out to be inconstant in their faith (or rather: in their allegiance to the Uniate church). This was the case of, e.g. the Polotsk bishop Gedeon Brolnicki, who came to reason only when Pociej threatened to dismiss and excommunicate him (in a letter dated April 25, 1604). The Metropolitan tried to convince Sigismund that he tested every single candidate for a higher church office, whom he recommends to the king, and that all of them declared (also in writing) a profession of faith that conformed to the rules of the Union of Brest, including the Roman 'filioque'. ${ }^{38}$ Considering his earlier experience, Pociej requested the royal

36 C. Lucaris to Paul V, November 7, 1608, cf. G. Hofmann, 'Patriarch Lukaris und die Römische Kirche', Orientalia Christiana, 15, 1929, 1, Appendix 1, pp. 44-46; Kempa, 'Wizyty...', op. cit., p. 102.

37 Later, Pociej assessed rather harshly Andrzejewski's activity as a bishop, describing him as a 'simpleton'. His main merit was, however, the allegiance to the Union of Brest. See A. Gil, Chetmska diecezja unicka 1596-1810. Dzieje i organizacja, Lublin, 2005, p. 59. 38 Pociej described it in a similar way early in 1601, in his letter to Radziwiłł 'Sierotka': "Nie wadziłoby, żeby pierwej do mnie na examen byli odsyłani, aniźli od Jego Królewskiej Mości przywileja otrzymają, bo każdego łatwie będzie poznać circa professionem fidei secundum ritum Romanae Ecclesiae, aniż po hramotach dawnych ruskich, które w sobie żadnego obligu nie mają. Alias ja bym żadnego konsekrować nie mógł, który by takiej professiej Summo Pontifici nie uczynił, jakom ja ją udziałał [?]. Moje sumnienie w tym, mnie to dojrzeć potrzeba, ponieważ nie z Rzymu sakra idzie. A gdy 
nomination charters to include a proviso that the candidate will lose the post in case he leaves the Uniate church - as an additional guarantee against a possible desertion. It should be noted that even that did not prevent similar occurrences. A particularly severe blow for the Union of Brest was the nomination of Jeremiasz Tyssarowski as the Bishop of Lvov in 1607 (after Bałaban's death). ${ }^{39}$ Immediately after having received the nomination charter, Tyssarowski turned to Moldavian bishops to be ordained, and he urged the faithful of his eparchy to persevere in the Orthodox faith..$^{40}$ As the result of that 'mistake', the Lvov eparchy remained in the Orthodox hands until 1700.

In his letters to the king (dated December 16, 1603, March 2n and April 25, 1604), Pociej raised the important issue of the dependence of Eastern churches in the Commonwealth on laymen. ${ }^{41}$ Paweł Uchański (a Catholic!) was entitled (for 30 years) by Stephen Báthory to nominate Chełm-Belz bishops. This gave him the control over all church estates of that eparchy. As indicated by the letter, it was Uchański's decision - in accordance with the Báthory's charter - that in 1585 it was a commoner, Dionizy Zbirujski, who became the bishop. He remained n office until 1603, unable to win respect or authority among locals - because of his background and the eparchy's poverty. After the death of Zbirujski, the Metropolitan of Kiev tried to enhance the prestige of the office, by choosing a candidate from among the nobility. The king accepted the candidacy of Iwan Andrzejowski. To regain the estates of the Chełm eparchy (still controlled by Uchański's widow, Anna née Herburt), was a much harder task.

który pierwej otrzyma nominacyją, swarz że się z nim o professią, a on już dzierży, a zatym może i do scyzmatyków udać się po konsekracyją, którzy go radzi przyjmą". Quoted after Żukowicz, Siejmowaja borba..., op. cit., p. 409, note 861.

39 The charter concerning the nomination of Tyssarowski as the Lvov bishop, dated October 31, 1607, in $A Z R$, vol. 4, no. 174, pp. 261-62.

40 Cf. Kempa, Wobec kontrreformacji..., op. cit., p. 246.

41 It was a serious problem already before the Union of Brest. It may be even suggested that this was one of the reasons for the Orthodox bishops to seek the unification with the Roman church. However, after the Union of Brest, it was impossible to completely eliminate the problem, and conflicts over properties with the Catholic church only added to it. See T. Kempa, 'Kościół unicki w Rzeczypospolitej do połowy XVII wieku. Czynniki sprzyjające rozwojowi unii brzeskiej i hamujące jej wzrost', in Między Zachodem a Wschodem. Studia z dziejów Rzeczypospolitej w epoce nowożytnej, ed. by J. Staszewski, K. Mikulski, and J. Dumanowski, Toruń, 2002, pp. 370-71. 
The letters of Pociej shed also some light on relations within the Uniate episcopate, which were far from being ideal. The Metropolitan complained about the uncertain allegiance of the Polotsk Bishop, Gedeon Brolnicki, while praising the Bishop of Turów-Pińsk, Paisjusz Sachowski, who took up the eparchy after the death of Jan Hohol in $1602 .{ }^{42}$ The strongest influence on the union's functioning was that of Lutsko-Ostrog bishop Cyryl Terlecki - beside Pociej, the most eminent of the architects of the Union of Brest among the Ruthenian bishops - who displayed a significant passivity at that time and avoided any contact with the head of the Uniate church. As it can be read between the lines of Pociej's letter dated April 25, 1604, Terlecki resented the fact that it was Pociej, and not him, who has been appointed as the Kiev Metropolitan, ${ }^{43}$ despite of his much longer experience as a bishop. ${ }^{44}$ Moreover, as a gratification for his support to the Union of Brest, Terlecki was granted by Sigismund III in 1596 the Kobryń monastery, ${ }^{45}$ which he was unable to control. The monastery was attached at that time to the Turów-Pińsk eparchy, and Pociej backed up the Turów-Pińsk bishops in the conflict over the monastery, acting against Terlecki. The latter had, actually, numerous other problems with the possessions of his eparchy, controlled by lay officials, as evidenced by his letter to Sigismund III (published herewith in the Appendix).

The Starost of Euck (and Castellan of Bracław) Mikołaj Siemaszko ${ }^{46}$ has not only annexed some of the eparchy's estates, but he also destroyed a wooden manor house, belonging to Terlecki and his chapter, ay the castle in Łuck. The manor house could have been destroyed because of an old feud between Terelcki and the Siemaszko family over its localisation.

42 Paisjusz Hipolitowicz became the Pińsk-Turów bishop thanks to efforts of Pociej and his supporter at the court of Sigismund III, Lew Sapieha. Cf. H. Pociej to Lew Sapieha, November 26, 1602, in $A D S$, no. 420, pp. 351-52.

43 Cf. H. Pociej to L. Sapieha, April 5, 1603, in $A D S$, no. 437, p. 368.

44 It was already in 1576, that Terlecki became the Turów-Pińsk bishop, and since 1585 he was the Lutsk-Ostrog bishop. Additionally, in 1589, he was appointed by the Patriarch of Constantinople, Jeremias II, as a temporary exarch in the Kiev metropolia. Pociej, on the other hand, became the Volodymyr-Brest bishop only in 1593 .

45 Cf. $A Z R$, vol. 4, no. 96, p. 133.

46 Interestingly, Mikołaj Siemaszko, as a Roman Catholic, was among the Volhynia nobles supporting the Union of Brest. This, however, evidently did not influence his attitude towards the Uniate church and its hierarchs. Cf. A. Kamieński, 'Kariera rodu Siemaszków w XV-XVII wieku', Lituano-Slavica Posnaniensia. Studia Historica, 3, 1989, p. 198; M.W. Dowbiszczenko, Wotynska szljachta u relihijnych ruchach kincja XVI-pierszoji potowyny XVII st., Kiev, 2008, p. 593. 
Namely, it was built next to the cathedral church, in the middle of the castles main courtyard. Ant it was where the father of Mikołaj Siemaszko, Aleksander (who was also the Starost of Łuck) planned to build his residence. ${ }^{47}$

The contents of subsequent letters (dated November 9 and December 27, 1611) shows clearly, how helpful was Lew Sapieha for the Metropolitan and the Uniate church as a whole. It was through his agency that Pociej solicited for new charters to be granted of old ones to be confirmed. It was, among others, the nomination charter for Józef Welamin Rutski, who was to become the Coadjutor bishop of the Kiev eparchy. Thanks to Sapieha's support, Pociej could have influenced the nomination of his successor as the head of the Uniate church.

Considering Sapieha's role in the development of the Union of Brest, Pociej reacted nervously to any information which could indicate that the chancellor's attitude toward the Orthodoxes may change. In a letter dated June 17, 1612, the Metropolitan mentions the alleged reconciliation, at the funeral of princess Zofia Radziwiłł née Olelkowicz, between Sapieha and one of the most active members of the Vilnius brotherhood - Iwan Poroszko. In 1597, Sapieha wrongfully accused the wealthy Vilnius burgher of spying for Moscow. This accusation was actually an assault on the objectors to the union, who were gathered around the Vilnius brotherhood, in order to obstruct the construction of the church of Holy Spirit. Poroszko, however, gained a support from the Vilnius voivode, Krzysztof Radziwiłł 'Piorun', and the construction of the church progressed unobstructed. ${ }^{48}$ It cannot be excluded that the attitude of the Chancelor of Lithuania to the Union of Brest and to the Orthodoxy started to change already in $1612.4^{49} \mathrm{~A}$ few years later he

47 Kamieński, op. cit., pp. 195-98.

48 More on this matter: J. Sprogis, Popytka wilenskago magistrata obwiniti odnogo iz bratczikow wilenskagoprawostawnago Swjato-Troickago bratstwa wgosudarstwiennoj izmien (1597 g.), Vilnius, 1897 (an offprint from Litowskie Jeparchialnyje Wiedomosti), pp. 4-19; Żukowicz, Siejmowaja borba..., op. cit., pp. 306-10; Kempa, Wobec kontrreformacji..., op. cit., pp. 135-36; idem, 'Współpraca prawosławnych i ewangelików...', op. cit., pp. 156-58.

49 It was only a few months earlier that Sapieha criticised severely the activity of the brotherhood of Holy Spirit. He accused its members of inciting religious unrest in eastern cities of the Grand Duchy of Lithuania, and even of maintaining secretly contacts with Muscovia which was at war with the Commonwealth at that time. Cf. L. Sapieha to the Vilnius brotherhood, January 19, 1611 (draft), Library of the Polish Academy of Learning and Polish Academy of Sciences in Cracow, 354, 11. 73-74. 
openly criticised some actions of Uniate bishops and their methods to 'convert' the Orthodoxes to the union. ${ }^{50}$

The letters published herewith illustrate problems that the creators of the Union of Brest had to face. The majority of them was, actually, caused by actions of Uniate bishops themselves, e.g. frauds between them, not necessarily in accordance with the spirit of the Christian methods to 'convert' the adherents of the Orthodoxy. On the other hand, there were also conflicts with Roman Catholics who - in their vast majority - did not appreciate the needs of the evolving Uniate community. The letters have been edited according to Instrukcja wydawnicza dla źródet nowożytnych (Editorial guidelines for modern sources). ${ }^{51}$ The writings are quoted in extenso, including introductory and concluding formulae, which reflect the attitude of Pociej to the addressees. All acronyms used intentionally by the author have been worked out, but without square brackets. These are used to mark author's unintended omissions. To display the peculiarity of the language, the groups 'en' and 'em' have not been corrected to 'ę' and vice versa (e.g. in the word 'mię'). Similarly, in the letter of Cyryl Terlecki the characteristic (although used inconsistently) cluster 'scz' (e.g. in the word 'Miłosczy') has not been corrected.

Translated by Kamil Kuraszkiewicz

First published as: 'Nieznane listy metropolity kijowskiego Hipacego Pocieja - ważne źródło do początków unii brzeskiej', Odrodzenie i Reformacja w Polsce, 54, 2010, pp. $179-218$.

50 As evidenced by the famous Sapieha's letter to the Połock Archbishop Jozafat Kuncewicz, dated March 12, 1622 (published, among others, in T. Żychiewicz, Jozafat Kuncewicz, Kalwaria Zebrzydowska, 1986, Appendices, pp. 159-71), the authenticity of which was challenged, but also by other letters dating from that period. See: Jozef Welamin Rutski to Lew Sapieha, April 2, 1622, and May 5, 1622, in T. Kempa, 'Nieznane listy biskupów unickich do kanclerza Lwa Sapiehy - źródła ukazujące sytuację wyznaniową w Wielkim Księstwie Litewskim w pierwszej połowie XVII wieku', Białoruskie Zeszyty Historyczne, 22, 2004, pp. 209-12; consignment note of the letter of J.W. Rutski to L. Sapieha (spring 1622), Centralnyj dierżawnyj istoricznyj archiw Ukrajiny (Kiev), f. 48, op. 1, no. 371; Jozafat Kuncewicz to L. Sapieha, January 21, 1622 and April 22, 1622, in Żychiewicz, op. cit., Appendices, pp. 156-58, 176-84. Cf. also Kempa, 'Kanclerz Lew Sapieha... ', op. cit., pp. 39-40. Kuncewicz ordered the Orthodox churches to be closed in Mohylew, where Sapieha was the starost; this infuriated the Lithuanian magnate.

51 Instrukcja wydawnicza dla źródet historycznych od XVI do potowy XIX wieku, ed. by K. Lepszy, Wrocław, 1953. 


\section{Hipacy Pociej to the Chancellor of Lithuania Lew Sapieha}

from the metropolitan court [in Vilnius], without date ${ }^{52}$ [2nd half of 1600] Original (written by a secretary)

Centralnyj dierżawnyj istoricznyj archiw Ukrajiny (Kiev), f48, op. 1, MS 372

Jaśnie Wielmożny a Miłościwy Panie Kanclierzu, Panie mój Miłościwy

Nie mając czasu wolnego z Waszą Miłością ustnie [się] rozmówić, muszę to przez papier odprawić, a proszę jako swego Miłościwego Pana, abyś Wasz Mość tę cedułę moją łaskawie przyjąwszy wolnego czasu cum deliberatione przeczytać raczył.

I do tych czasów chowam u siebie pro sacro sancto list Jego Królewskiej Mości własnej ręki Wasz Mości z Krakowa pisany jeszcze przed tą unią naszą opłakaną, gdzie mi Jego Królewska Mość łaskę swą pańską, obronę i wszelaką pomoc, gdzie by jaka potrzeba przypadła, tak na nas jako i na kościoły nasze, obiecować raczy, kiedyśmy do tej jedności świentej przystempowali, czegośmy z pierwu po części doznawali. Lecz teraz wielka cierzpliwość pańska i oczekiwanie niejakie opamiętanie adwersarzów naszych do takiej insolencyjej i swejwoli scyzmatyków naszych przywiodła, że też tylko tego nie dostaje, aby nas z miejsc naszych powyrzucali, bo nie mogąc na sejmiech tego przewieść, aby nas degradowano, atoli z inszej miary takie nam sztuki wyrządzają, że tylko nomine et non re jesteśmy biskupami, bo nam nie tylko owieczki nasze, ale też i kapłany, i sługi kościelne swoimi przewrotnemi sztukami poodejmowali.

Władyka lwowski apostata nasz mało miał na tym, iż w odjachaniu Jego Królewskiej Mości do Szwecjej wszytkę mi diocesją moję włodzimierską odjąt, popów nastawiał, ekskommunikacyje, aby mię nie słuchali, rozsyłał. Ale a to i do tego przyszło, że i tu do Wilna na wielką żałość i wzgardę moję dwu popów poświęcit, na mnie nic nie dbając, nie tylko na one uniwersały Jego Królewskiej Mości, które po synodzie brzesckim skoro były wydane, ale też i na list Jego Królewskiej Mości prywatnie do niego pisany już z Szwieciej, przyjachawszy serio mu grożąc prawem i chcąc przez instigatora o to z niem czynić. Ale on, psiną oczy zakrywszy, namniej o to nie dba, widząc, że mu się pierwsze przepiekło. Teraz co dalej, to wiencej, tak siłę bierze, że już i tu jako chce po swejwoli rozkazuje, mając

52 The lack of date and place in the letter indicates that the addressee must have stayed in Vilnius at that time. 
swoje instrumenta tu w Wilnie, Karpa i drugiego ${ }^{53}$, których na prezbiterstwo poświencił i tu do Wilna z jakimiś przywilejami przysłał, które soleniter w ich jaskini łotrowskiej publice czytano konfirmując ludzi w tej przeklentej scyzmie. Tego tylko nie wiem czy jego czy patriarsze, i tak posteriora facta sunt peiora prioribus. A ja tylko tu ścian strzegę i z swojemi biednemi popami, którzy mi żalem będąc uwiedzeni, nieraz oczy tym kolą, iż ani ja, ani oni ratunku od złych ludzi nie mamy. Wienc onym wszytko wolno, a my zasię i roz- postrzec się przed niemi nie możemy.

Słyszałem od niektórych ludzi pewnych, żeby z ich tam ordy nie mało było takich, którzy by radzi do nas się udali, ale widząc niepotężność naszą, a ich zaś siłę nie śmieją, bowiem ekskomunikacyje i zakłady na nich wkładają. Dał był Pan Bóg, żeśmy zbyli Zyzanię ${ }^{54}$ a teraz na to miejsce kilka jeszcze gorszych nastąpiło. Nie wspominam, jakie ekscessy niesłychane $\mathrm{w}$ tym rozerwaniu naszym między duchownemi dzieją się. Czerńcy się żenią, popi popów stawią, drudzy publicas orationes za nieprzyjacielmi pana naszego prosząc Boga o zwycięstwo nad Jego Królewską Mością, czynią proroctwa na kazaniach, o Mi[c]halu jawnie przywodzą, że go Bóg wzbudził ad vindictwa nad Rzymiany pro religione Ruthena et multa alia, czego bym i na kilku arkuszach nie wypisał. A my zaś choca byśmy radzi złych skarali i do uspokojenia rzeczy takie niepobożne przywiedli, ale nie możemy, bo właśnie jako związane ręce mamy, jużeż by mniej się mówiło, gdzie by w dobrach szlacheckich to się działo. Ale to nacięższa, iż w dobrach i w mieściech Jego Królewskiej Mości taką wzgardę cierzpiemy. Przeto mali być tego dłużej, ja się Wasz Mości memu Miłościwemu Panu deklaruję, iż ja metropolią pożegnam. I owszem proszę, i dla Pana Boga proszę, abyście Wasz Mościowie kogo młodszego, który by tym pracam i kłopotam sprostał albo żeby umiał przez spary na te złości patrzyć, obrać

53 The priests Karp Łazarowicz and Hrehory Żdanowicz.

54 Stefan Zizania (Kąkol), a renown polemicist and preacher, teacher in brotherhoods' schools in Lvov and then in Vilnius, a fierce objector to the union, was among the first to incite the citizens of Vilnius against bishops who promoted the union with the Roman Catholic church. On those events and the role of Zizania in them, see: T. Kempa, 'Nieznane listy dotyczące genezy unii brzeskiej', op. cit., nos. 6-8, 17-18, pp. 116-19, 125-26. Zizania has been excommunicated by the council in Nowogródek (officially because of his yielding to Calvinist influences) in January 1596 (cf. $A Z R$, vol. 4, no. 91, pp. 125-26; cf. ibid., nos. 88, 92, 95, pp. 121-22, 127-28, 132-33). Despite of having been excommunicated and banished by Sigismund III, he stayed in Vilnius until 1600, when he was killed, according to some sources. See: S.A. Padokszyn, Reformacija i obszczestwiennaja mysl Belorussii i Litwy (wtoraja pol. XVI - nacz. XVII w.), Minsk, 1970, pp. 182-97. 
raczyli, a mnie z tego ciężaru przyczyną swą u Jego Królewskiej Mości wyzwolili, gdyż widzi Bóg, iż mi się przyjdzie bez czasu albo oszaleć albo nagle umrzeć, tak mię barzo zgryzło, patrząc na wielki upadek Kościoła Bożego i owieczek sprośnie zawiedzionych, którym, jakeśmy powinni, ratunku dać nie możemy nie mając po sobie żadnej potężności.

Albo jeszcze Wasz Mościowie panowie katolikowie chcecie, abym w tym jarzmie i do ostatniego wytchnienia mego ciagnnął dla Pana Boga i dla chwały jego świentej, proszę, i płaczliwie proszę, nie dopuszczajcież Wasze Miłości Kościołowi Bożemu i nam sługam Jego takiej nieznośnej krzywdy cierzpieć, gdyż to Wasz Mościowie macie w ręku swoich, byle byście chcieli, możecie nas zawżdy obronić i podeprzeć. Upominamy się Wasz Mościom obietnice, którą-ście nam sacro sancto, ciągnąć nas do tej jedności, uczynili. Nie dajcież Wasz Mościowie nie tylko sobie, ale i majestatowi pańskiemu takiej zelżywości i despektu wyrządzać. Macie Wasz Mościowie siła sposobów sprawiedliwych i prawnych, że tę swąwolą pohamować możecie. A póki Wasz Mość mój Miłościwy Pan z Jego Królewską Mością o tym konferować będziesz raczył, proszę pilnie, abyś Wasza Mość po Karpa i po drugiego popu swowolnego sobie posłać raczył i jako Pan Bóg Wasz Mości nauczył z baczenia swego wysokiego, tak to im pokazał i serio o tym mówił, jeśli się to godziło i wedle Boga, i wedle kanonów kościelnych z diocezjej biskupa swego do inszego biskupa po konsekracyją biegać. I jeszcze to niejawnie przeciw majestatowi pańskiemu i przeciw onym listom, które Jego Królewska Mość do Szweciej jadąc wydać za Wasz Mości instancyją raczył, aby się jeden drugiemu w diocesią ani w sprawy duchowne, ani w kościoły nie wtrącał, czynią, czego my i do tych miast pilnie strzeżemy i nie pokażą na nas namniejszej maculii, a my bez liczby pokażemy, jako wiele krzywd od nich mamy. Jest k temu i dawne synodowe postanowienie w tych państwach, iż jeśliby się który władyka w drugą diocezją wtrącał, kilkaset rubli ${ }^{55}$ Jego Królewskiej Mości taki zapłacić powinien będzie i to by niemały przystemp do pohamowania swejwoli był. Cóż nam i po uniwersalech i po liściech Jego Królewskiej Mości, kiedy efektu swego nie mają. Oto i teraz pop, wyklenty od antecessora mego i od Jego Królewskiej Mości banniowany, Wasilej tu mieszka ${ }^{56}$. Czym ten lepszy nad Zyzaniego, który umykać musiał, a ten śmieszki ze wszystkiego stroi.

55 One ruble $=100$ threescores of Lithuanian groschen.

56 One of the two (with Herasym) Orthodox priests associated with the Vilnius brotherhood, who have been excommunicated by the council in Nowogródek in January 
Proszę tedy i po wtóre Wasz Mości swego Miłościwego Pana, abyś Wasz Mość ex autoritate sua jako stróż pokoju pospolitego onych nakarał, kazawszy im do siebie przyść, gdyż z wielkim postrachem na Wasz Mości samego barzo się oglądają. A zaliby za upomnieniem Wasz Mości mogli się ze mną jako zgodzić, gdyż i między niemi jest ich niemało, co by radzi tej zgodzie, widząc, iż nic nowego nie mają, a k temu i moję wielką cierzpliwość, tylko nie mają wodza, któryby im calcaria przyłożył. Pewienem tego, iż Wasz Mości z niemi rozmowa wielce mi będzie pożyteczna i Kościołowi Bożemu barzo potrzebna.

Inszych dolegliwości swoich i wypisać nie mogę. Tylko do Pana Bogę wzdycham, a zawżdy et hic dabit finem. $\mathrm{Z}$ tym służby i modlitwy moje ubogie kapłańskie zalecam łasce Wasz Mości mego Miłościwego Pana i szczęśliwej a dobrej nocy winszuję.

Dan z dworu metropolego.

Wasz Mości swego Miłościwego Pana $\mathrm{Na}[\mathrm{j}]$ niższy Sługa i Bohomoliec

Hypathius Metropolita

2. Hipacy Pociej to the voivode of Troki Mikotaj Krzysztof Radziwitt 'Sierotka' Vilnius, June 1, 1601

Original (written by a secretary)

Library of the Polish Academy of Sciences in Kórnik, MS 1539, no. 64

Oświecone Miłościwe Książę, Panie mój Miłościwy

Mając pewnego posłańca w tamten kraj do Waszej Książęcej Mości umyślnie tym pisaniem moim służby i modlitwy moje łasce Waszej Książęcej Mości zalecam, życząc od Pana Boga przy łasce jego świentej dobrego zdrowia i fortunnego panowania Waszej Książęcej Mości na wiele lat.

Nimiapacentia panów katolickich przywiodła naszych scyzmatyków do takiej insolencyjej, że już i sami nie wiedzą, co broją. O których żeby się mieli kiedy obaczyć, nie tylko żeby była jaka nadzieja, ale co [da] lej, to wiencej w przeklętym uporze i w scyzmie zastarzałej utwierdzają

1596 for criticising the Metropolitan and other bishops (who supported the union), and then banished by Sigismund III (cf. $A Z R$, vol. 4, no. 91, pp. 125-26; ibid., no. 95, pp. 132-33). It is evident that Wasyl, despite of having been banished, lived still in Vilnius. 
się. Jakoż i teraz niedawno dwaj z mieszczan wileńskich jeździli aż do Lwowa po ordynacyją do władyki lwowskiego, który nie tylko, że mi tam moją diocezją włodzimierską odjął, ale już mię i ówdzie dalej niż przez sto mil dosiągł. Czegoż się my dalej dobrego spodziewać mamy, kiedy oni nie mając po sobie ani Boga, ani prawdy, ani pana, tak wiele złego broją. A my wszystko to mając za sobą i rozpostrzeć się z jurysdycyją swoją nie możem. A to nas najwiencej boli, że takiej obrony od panów katolików, jaka nam była obiecana, gdyśmy do jedności świentej przystempowali, nie mamy. Oni na sejmikach, oni na sejmach wołają, choca żadnej krzywdy nie mają i owszem nam ją, gdzie mogą, czynią. A my niebożenta i gemby otworzyć nie umiemy, i tak bezpiecznie o sobie rzec możemy, żeśmy są pastyrze tylko ścian gołych, a nie owieczek Krystusowych. Byłoby wiele sposobów słusznych i sprawiedliwych pohamować taką swąwolę, ale cóż, kiedy nie chcą, a tylko cierzpieć każą, a swawola i wszystko złe co dalej, to się mnoży.

I teraz ci dwaj popowie przynieśli jakieś przywileja z pieczęciami zawiesistemi perły osadzonemi. Nie wiem, czy patriarchy konstantinopolskiego, czyli wołyńskiego ${ }^{57}$, które cum magna solenitate na misje jako sakrament jaki, zwoławszy wszytko pospólstwo, do swej synagogi nosili obfuscando oculos ignobili vulgo, zatym klątwy, zatym interdykty, zatym rozmaite kalumnie na nas kładąc. Pospólstwu zakazują, aby z nich żaden do naszych cerkwi ani na nabożeństwo, ani na kazania, nie chodził. A jakoż tu ma być speranda conversio illorum, kiedy te media odejmują, przez które ludzie do poznania prawdy Bożej przychodzą. Widzi Pan Bóg wszechmogący, by mi nie szło o sumnienie, by mi nie szło o łaskę Pastyrza Najwyższego, uciekłbym z tego labiryntu do domu, a w kącie usiad[ $\mathrm{l}]$ szy opłakiwał nieszczęście i upadek Kościoła naszego i tak nie szlubuję za to, abym mógł wytrwać [w] tej ciężkiej niewoli, która nas zewsząd ogarnęła, że też już, co dalej czynić, nie wiemy. Wżdy we Włodzimierzu będąc bliżej herstów samych nie miałem takiego utrapienia, jakiego owdzie zażywam od tego przeklentego i swowolnego bractwa ${ }^{58}$, na które wszyscy niemal przez spary patrzą, a nam co dalej, to gorzej. Tylko do Pana Boga wołać: Domine di[scerne] [?] iudica causam nostram.

57 As the 'Volhynian patriarch' describes Pociej sneeringly the leader of the anti-Uniate camp - the voivode of Kiev Konstanty Wasyl Ostrogski.

58 An Orthodox brotherhood that functioned at the church of the Holy Spirit at that time, and earlier - at the church of the Holy Trinity. 
Ja ówdzie w Wilnie, chocaż tylko murów strzegę, jednak chciałbym króla doczekać, będzie li rychło i stanie li mi rozumu w mieszku, a potym do Mińska chciałbym wizytować. Nazad lepak do Nowogródka, tamże bym i Wasz Mości mego Miłościwego Pana nie minął, którego daj Panie Boże, abym dobrze zdrowego oglądał.

Będąc u Wasz Mości w Nieświeżu, widziałem formę grobu pańskiego drzewianą. Proszę pokornie swego Miłościwego Pana, abyś mi Wasz Mość raczył rozkazać taką drugą urobić stolarzowi, o których w Nieświeżu, wiem, że nie trudno. Będę to miał od Wasz Mości swego Miłościwego Pana za osobliwy upominek, gdyż mi się trafia często rozmawiać o tym, którzy tam dziwy powiadają i daleko różno od tego, jakom ja u Wasz Mości widział, a najwiencej o tych ogniach powiadają, iż grób pański otworzysty, że ogień nań z nieba spada. Wasz Mości swemu Miłościwemu Panu taką szczodrobliwą i miłościwą łaskę zasługować winien będę. A gdzieby jes[z]cze do tego i peregrinacyją Wasz Mości miałbym przepisaną, za osobliwy znak miłościwej łaski Wasz Mości i pro consolatione spirituali miałbym to u siebie.

Co wszytko łasce Wasz Mości swego Miłościwego Pana poruczam. A siebie samego i najniższe służby moje $\mathrm{z}$ modlitwami mojemi ustawicznemi łasce Wasz Mości iterum atque iterum zalecam.

Datt [w] Wilnie Junii 1 d. Anno Domini 1601.

Waszej Książęcej Mości swego Miłościwego Pana Najniższy Sługa i Bohomolnik Hypatius Dei et Apostolica Sedis gratiae Archiepiscopus Metropolita Kioviensi, Episcopus Wtadimiriensi ręką własną

\section{Hipacy Pociej to Mikotaj Krzysztof Radziwitt 'Sierotka'}

Nowogródek, September 30, 1601

Original (autograph)

Library of the Czartoryski Museum in Cracow, MS 2580 IV, Part 2, no. 65, pp. 257-59.

Oświecone a Miłościwe Książę, Panie a Panie mój Miłościwy Służby i modlitwy moje zaliecam łasce Waszej Książęcej Mości. 
Aczkolwiek o przybyciu Jego Mości Ks. legata do Nieświeża nic pewnego od Waszej Książęcej Mości nie mam, jednak jeśliby na ten czas, jako mi Wasza Książęca Mość pisać raczysz, przybył, obawiając się, żebym tyj cerimoni Świętej (którychem nigdy nie widał) nie omieszkał, zarazem puszczę się w drogę we wtorek, da Pan Bóg, abym do Waszej Książęcej Mości mógł na śrzodę przybyć, bo by mi nie wczas było czekać od Waszej Książęcej Mości drugiej wiadomości. Jednak jeśliby temi czasy Illustrissimis Nuntius do Waszej Książęcej Mości być nie miał, proszę swego Miłościwego Pana, abym mógł mieć wiadomość we wtorek na noc, do imienisza mego Bykowicz, które mi jest w pół drogi do Nieświeża jadąc, bo bym tam chciał być na noc we wtorek, abym się zaś do Nowogródka wrócił, nie discomodując Waszą Mość na ten czas przyjachaniem moim niepotrzebnym, odłożywszy to na on czas, aż kiedy Jego Mość Ks. legat przybendzie.

Aczem ci tu w tych krajach nie miał woli długo mieszkać, dlia wielkiego nieurodzaju, którym nas Pan Bóg nawiedził, do czego nam i panowie żołnierze nie [ss] pomogli. I umyśliłem był zaraz, koniom odpo- czynąwszy, na Podliasze, a stamtąd na Wołyń, alie widzę, żeby mi na ono wyszło fugiens Charibdim incidis in Scillam ${ }^{59}$, bo nie tylko w Brześciu, gdzie się i moja biedna chałupa od powietrza srogiego nie wybiegała, alie, jako mi piszą, że już i we Włodzimierzu, i w inszych miasteczkach okolicznych mrze barzo. Zgoła nas Pan Bóg wszystkimi przedniejszymi plagami swojemi chlusta, głodem pewnym, powietrzem i mieczem nieprzyjacielskim. A strzeż Panie Boże, aby nie ostatnim zginieni[e]m, prosić Pana Boga, aby nie patrzył na złości nasze, alie na miłosierdzie swoje. Alim zaprawdę za naszymi miłemi żołnierzami wliecze się płacz i narzekanie ludzi ubogich, panienek i białych głów uczciwych, bo nie masz tej niecnoty, której by się nie ważyli, tak że sobie [na] błogosławieństwo od liudzi zasłużyli. Muszę tedy, rad nie rad, w tych krajach czekać miłosierdzia Bożego, jako mogąc, żywiąc się, aż Pan Bóg w tamtych krajach gniew swój uśmierzy.

Ostatek odkładam do ustnej rozmowy z Waszą Książęcą Mością, Panem moim Miłościwym, któremu i [ ${ }^{60 a}$ służby moje najniższe pilnie zaliecam, prosząc Pana Boga, abym Waszą Książęcą Mość zdrowego ogliądał.

59 A reference to the Latin saying 'incidis in Scyllam, cupiens vitare Charybdim' (an equivalent of 'to fall out of the frying pan into the fire'). Skylla (Gr.), today Scilla, a rock shoal on the Italian side of the Strait of Messina, opposite the Charybdis whirlpool off the Sicilian coast. In the Greek mythology - two sea monsters that lurked on both sides of the Strait of Messina to abduct sailors. Cf. Homer, Odyssey, Book 12, 235. 60 a An illegible word, covered by sealing wax. 
Dan z Nowogródka ultima Septembris Anno Domini 1601.

Waszej Książęcej Mości Pana swego Miłościwego najniższy sługa i Bohomolnic Adam Pociej Archiepiscopus Metropolita Kioviensis

[postscript:] Bykowice moje leżą [?] wedlie Cyryna, aby posłaniec Waszej Książęcej Mości wiedział.

\section{Hipacy Pociej to King Sigismund III Vasa}

Wtodzimierz, April 22, 1602

Original (written by a secretary)

Library of the Polish Academy of Sciences in Kórnik, MS 1401, no. 22, ll. 75-76

$\mathrm{Na}$ [j] jaśniejszy a Miłościwy Królu, Panie a Panie nasz ${ }^{61}$ Miłościwy Jako wielą rozmaitych darów swoich Pan Bóg Wszechmogący panowanie Waszej Królewskiej Miłości w tych państwach zdobić raczy, tak nie mniej i tą jednością Świętą, której Wasza Królewska Miłość po Panu Bogu pierwszym autorem raczyłeś być i za wieków panowania swego oglądać-eś ją raczył w państwie swoim między poddanemi swemi, iż teraz co przedniejszy pastyrzowie Kościoła Ruskiego, odnowiwszy onę unię świętą na concilium florenskim ${ }^{62}$ uczynioną pod posłuszeństwem powszechnego pastyrza Kościoła pana Christusowego i stolice Piotrowej, Pana Boga w Trójcy jedynego chwalą i za dobre zdrowie a fortunne panowanie Waszej Królewskiej Miłości i świętego potomstwa Waszej Królewskiej Miłości u ołtarza jego świętego ustawicznie proszą. A chociaż jest niemało przekaz dusznego nieprzyjaciela, jako to w sprawie Bożej zwykło bywać, także i adwersarzów tej Świętej jedności, którzy by to święte dzieło radzi wniwecz obrócili, ale ufam miłosierdziu Bożemu i obronie Jego świętej, iż portae inferni non praevalebunt. Jednak Pana Boga wziąwszy na pomoc, w tak dobrej i świątobliwej sprawie nie godzi się ustawać, ale do końca staranie czynić, jakoby i ci, którzy jeszcze między opłotkami tułają się adgraemium Ecclesiae Sanctae byli przywiedzeni, aby się napełnił dom pański i ta miła

61 Noteworthy is the address; apparently, Pociej speaks - here and in other letters to the king - on the behalf of the whole Uniate community, though formally the letters are signed by him alone.

62 Obviously, the council in Ferrara and Florence (in the years 1438-39). It was then that the union between the Orthodox and Catholic churches has been signed. 
owczarnia jego w państwach Waszej Królewskiej Miłości. Za czym też i pokój między poddanemi Waszej Królewskiej Miłości i wszytkie insze sprawy R[em] P[ublicum] spokojniej odprawować by się mogły, niejako po te czasy, których napatrzyliśmy się, że też niektórzy i sejmy tym rozrywać, i Rzeczy Pospolitej odbiegać, i w niebezpieczeństwo przywodzić nie wstydzili się. Jakoż i teraz jeszcze adwersarze jedności Świętej nie chcą się uspokoić i podobno co dalej, to więcej turbować usiłują, jeśli temu nie zabieży autoritas Waszej Królewskiej Miłości. A ile pod tym czasem gdzie się nie lada okazyja do uspokojenia podaje.

Przeto z powinności mojej, jako sługa Kościoła Bożego i wierny poddany Waszej Królewskiej Mości, Panu mojemu Miłościwemu daję znać, iż niejaki Cirillus Magnus, archimandrita Alexandriae, człowiek godny i Kościoła katolickiego przyjaciel wielki a ossobliwie tej jedności Świętej barzo przychylny, który też nie pojedenkroć bywał w państwach Waszej Królewskiej Miłości i miewał rozmowy, i porozumienie z niektóremi wielkiemi stany de unione sancta, został patriarchą konstantynopolskim ${ }^{63}$, zaczym jest nadzieja w miłosierdziu Bożym, iż za pastyrstwa jego in Ecclesia Dei może się co dobrego sprawić. ${ }^{64} \mathrm{~A}$ chocaż nie wszendzie, gdyż servitus pogańska nie dopuszcza, dosyć by dobrego było, kiedy by w państwie Waszej Królewskiej Miłości pokój między nami poddanemi Waszej Królewskiej Miłości uczynił, a przeciwnikom jedności Świętej rozkazał, żeby się radczej [s] z nami bracią swą, którzyśmy są in unione, aniźli z heretykami, nieprzyjacielmi Kościoła powszechnego, zgadzali.

Nie bez przyczyny piszę do Waszej Królewskiej Miłości o tym, bo jest jego własne rękopisanie i konfesyja u Jego Mości księdza arcybiskupa lwowskiego, w której obiecał się starać o tę Świętą jedność u patriarchów swoich, kiedy z tych krajów odjeżdżał. A jeśliże wtenczas będąc sługą ich, był dobrej woli do tej Świętej jedności, teraz i owszem, kiedy sam został starszym patriarchą, byleby non mutaret animum, mógł[by] wiele dobrego Kościołowi Bożemu zdziałać. Jakoż i to niemniejsza przyczyna pisać do niego, w tym go upomnieć, iż ówdzie w państwach Waszej Królewskiej Miłości, tak wielie metropolitów i władyków dzikich najachało się,

63 Pociej was evidently misinformed, as Cyril Lucaris was elected at that time as the Patriarch of Alexandria, after the death of Meletius Pagas who was his mentor in religious matters. It was to him that Lucaris owed his fast career in the church hierarchy. 64 During the last Lucaris' stay in the Commonwealth in 1600-01, Pociej solicited for the expulsion of the Greek priest from the country. He suspected that the real reason of Lucaris' visit was to consolidate the political cooperation between the Protestant and Orthodox churches, also in the context of counteracting the Union of Brest. 
którzy nam sługam i bohomolcam Waszej Królewskiej Miłości wszytkę władzą i jurysdycyją odjęli, nasze urzendy za siebie zabrali i tak nas barzo ścisnęli, że też i rozpostrzeć się nie możemy, a tylko filutem pastyrzmi, a nie rzeczą, jesteśmy. Zaczym i autoritas Waszej

Królewskiej Miłości w lekkie poważanie przychodzi i ta świenta jedność nie tylko żeby się miała pomnażać, ale co dalej, to więtsze detrimentum bierze, duchowni swejwoli zażywają, między któremi takie ekscessy dzieją się, że też i między pogany takie nie najdują się. Karać trudno, swawola górę wzięła. Tamtych dzikich władyk nie słuchają, a nas pogotowiu za nic mają. Jeśliby też nie zdało się Waszej Królewskiej Miłości do niego o to rozkazać pisać, więc choca Jego Mości Ks. arcybiskupowi lwowskiemu to negocium zlecić, aby z nim przez pisanie swoje o to traktował i słowa się onemu upominał, które tu na piśmie zostawił. A zatym może Pan Bóg serce jego tak utwierdzić, iż pomniąc na obietnicę swoję, uczyni do dobrego i pamięci godnego ku chwale Bożej za pastyrstwa swego. A choca by w państwie Waszej Królewskiej Miłości uspokoił przeciwników naszych i za to mielibyśmy za co Panu Bogu dziękować, póki co lepszego nastąpi.

Ja jeden, ubogi kapłan sługa i Bohomolca Waszej Królewskiej Miłości, uniżonemi prośbami mojemi o to pilnie proszę, abyś Wasza Królewska Miłość jako począł, tak i do końca w tej Świętej sprawie starania swego królewskiego czynić zaniechać nie raczył. A Pan Bóg Wszechmogący, jako na tym świecie fortunnemu panowaniu Waszej Królewskiej Miłości błogosławić bendzie raczył, tak i w przyszłym żywocie hojną zapłatą królestwa wiecznego pewnie nagrodzi i te wszytkie prace i starania pobożne, które Wasza Królewska Miłość jako prawy król katolicki dla chwały imienia Jego Świętego i dla rozszyrzenia Kościoła krześcijańskiego podejmować raczysz, zapłaci.

Zatym służby moje najniższe $\mathrm{z}$ wiernym poddaństwem i modlitwy kapłańskie zalecam Miłościwej łasce Waszej Królewskiej Mości.

Dan z Włodzimierza Aprilis 22 Anno Domini 1602.

Naj[j]aśniejszego Majestatu Waszej Królewskiej Miłości uniżony sługa i Bogomolca Adam Pociej Dei et Apostolicae Sedis gratiae Archiepiscopus Metropolita Kiovensis et totius Russiae, Episcopus Wtadimiriensis ręką własną 
5. Hipacy Pociej to King Sigismund III Vasa

Wtodzimierz, April 29, 1602

Original, written by a secretary (the same who wrote the letter of April 22, 1602)

Library of the Polish Academy of Sciences in Kornik, MS 1401, no. 23, p. 79

Naj[j]aśniejszy a Miłościwy Królu, Panie a Panie Nasz Miłościwy

Oznajmuję Waszej Królewskiej Miłości, iż cerkiew Zmartwychwstania Pana Christusowego z należnościami swoimi w mieście krzemienieckim wakuje. Widząc tedy na to człowieka godnego Theodora Turskiego posyłam go do Waszej Królewskiej Miłości, za którym Waszej Królewskiej Miłości swego Miłościwego Pana uniżenie proszę, abyś mu Wasza Królewska Miłość tę cerkiew, ze wszystkiemi jej należnościami wedle dawnych przywilejów świętobliwych przodków swoich, z miłościwej łaski swej dać raczył, żeby w tym domu Bożym chwała Boża nie ustawała i za dobre zdrowie a fortunne panowanie Waszej Królewskiej Miłości ustawiczna modlitwa odprawować się mogła.

A osobliwie Waszej Królewskiej Miłości oto pokornie proszę, aby w tych daninach Waszej Królewskiej Miłości i w przywilejach mianowicie tego dokładano, żeby byli pod posłuszeństwem Stolice Świętej Rzymskiej i swego własnego biskupa. A jeśliby inaczej czynili i posłuszeństwa biskupowi swemu oddawać et in unione sancta trwać nie chcieli, aby ipso facto prawo swoje tracili. Ponieważ niejeden już taki pokazał się, który otrzymawszy daninę z łaski Waszej Królewskiej Miłości i obiecawszy być pod posłuszeństwem et in unione sancta, potym najwiętszemi nieprzyjacielmi tej jedności Świętej pokazali się. Nawet ordines, mimo swego biskupa, u scyzmatickich przyjmowali, a prawie łaską Majestatu Waszej Królewskiej Miłości pogardzili. A mam li rzec salva reverentia Reverendis Maiestatis Vestrae oszukali. Przeto zdałoby mi [się] najsłuszniej, aby każdy taki, któryby się po jakie beneficia do Waszej Królewskiej Mości uciekał, żeby i oblig na siebie kancelariej Waszej Królewskiej Miłości dawał i taki, jako się wyszej pomieniło, a nie in- akszy przywilej z kancelariej Waszej Królewskiej Miłości otrzymywał. Bo drudzy i przysięgę cum professione fidei przede mną uczyniwszy nie zdzierżeli słowa; z któremi teraz najwiętsza trudność aniźli z scyzmatikami. Co wszytko miłościwej łasce Waszej Królewskiej Miłości i mędrszemu uważeniu poruczam. A zatym rękę Majestatu Waszej Królewskiej Miłości jako wierny poddany i Bohomolca ustawiczny całuję. 
Dan z Wtodzimierza 29 Aprilis Anno Domini 1602.

Naj[j]aśniejszego Majestatu Waszej Królewskiej

Mości wierny poddany i Bohomolca Hypatius Archiepiscopus Metropolita Kiowiae m[anu] p[ropriae]

\section{Hipacy Pociej to King Sigismund III Vasa}

Chmielów, December 16, 1603

Original, written by a secretary, paper severely damaged

Library of the Polish Academy of Sciences in Kórnik, MS 1401, no. 41, pp. $145-46$

Naj[j]aśniejszy a Miłościwy Królu Panie a Panie Nasz Miłościwy Antecesor Waszej Królewskiej Miłości, świętej pamięci król Stephan (jako to jeszcze władykam w scizmie będącym), oddał był władyctwo chełmskie panu Uchańskiemu, wojewodzie bełskiemu ${ }^{65}$ ze wszystkiemi dobry kościelnemi, na liat trzydzieści. Za czym pan Uchański obrawszy ubogiego człowieka, postawił tam władyką ${ }^{66}$, a tylko z ołtarza i z popów kazał mu się żywić, a do tego kilka chłopków w Chełmie przydawszy, ostatek majętności sam trzymał. A po śmierci jego Jej Mość pani wojewodzina bełska ${ }^{67}$ teraz trzyma, tamże i przywileja i fundusze kościelne zostali. Przyszło teraz do tego, że ten ubogi człowiek władyka chełmski $\mathrm{w}$ wielkiej mizerii i w niedostatku umarł, bo iż był in unione $\mathrm{z}$ nami, wzgardzili [n]im, nie tylko lud pospolity, ale i popowie swowolni. Teraz ta episkopia pusta wakuje i podobno długo wakować musi, bo znaczny żaden się nie waży o nie prosić widząc, iż [ $\left.{ }^{68 b}\right]$ też dawszy, toż się będzie działo, co i z pier[w]szym, bo pier[w]szego widząc, iż żadnej potężności nie miał i z miast niektórych Waszej Królewskiej Miłości, jako z Buska i z Sokala, kijmi i kamieńmi nieraz wyganiano i obel[ $\left.\mathrm{żo}^{69}\right]$ no. A iż był

65 Paweł Uchański was the voivode of Bełz in 1588-90, thus he must have been entitled by Stephen Báthory (ob. 1586) to nominate the Chełm-Bełz bishops earlier, before he became the voivode.

66 Dionizy Zbirujski, bishop of Chełm-Bełz in 1585-1603, since 1596 as an Uniate bishop.

67 The widow of Paweł Uchański, Anna née Herburt (ob. 1619).

68 b Lacuna, two words missing.

$69{ }^{\mathrm{c}}$ Lacuna, the missing letters added. 
$\left[\mathrm{u}^{70 \mathrm{~d}}\right]$ bogij i nędzny, nie mając za co i chleba kupić, nie mógł prawem $\left.{ }^{\left[{ }^{71}\right]}\right]$ czynić i tak $\left.{ }^{[2 f}\right]$ przysychało, cum maximo scandalo Ecclesiae Dei. Przeto $\left[\dot{\mathrm{z}}^{73 \mathrm{~g}}\right]$ zdało mi się z $\left[\right.$ a rzec $\left.{ }^{74 \mathrm{~h}}\right] \mathrm{z}$ słuszną Waszej Królewskiej Miłości o tym oznajmić i prosić, abyś Wasza Królewska Miłość raczył mieć miłościwy i ojcowski wzgląd na tę ubogą episkopią i napomnieć Jej Mość panię wojewodzinę, jeśliby czego do Kościoła Bożego ustąpić nie chciała, żeb $\left[y\right.$ choć $\left.^{75 i}\right]$ wi $\left[e^{76 j}\right]$ kszą arendę z tych majętności kościelnych postąpiła, $\operatorname{gd}\left[\mathrm{y} \mathrm{ty}^{77 \mathrm{k}}\right]$ lko snać dwa[dzieścia grzy $\left.{ }^{781}\right]$ wien arendy daje. A majętność kościelna jako mi powi[adają $\left.{ }^{79 m}\right]\left[{ }^{80 \mathrm{n}}\right]$ i więcej dwu[ $\left.{ }^{81 \mathrm{o}}\right]\left[{ }^{82 \mathrm{p}}\right]$ tych. A zatym mógłby się jaki dobry człowiek nalieść, k[83q] Waszej Królewskiej Miłości mógł z pożytkiem Kościoła Bożego i z pomnożeniem jedności Swię[tej $\left.{ }^{84 r}\right]$ trzymać.

Doszło mię też i to wiedzieć, że snać scizmatykowie niektórzy mają wolą Waszej Królewskiej Miłości o tę episkopią prosić, mało dbając na jej ubóstwo, bylieby ją otrzymawszy, a potym ze wszystkim do przeklięntej scizmy wrócić się. Przeto Waszej Królewskiej Miłości dla miłosierdzia Bożego proszę, abyś Wasza Królewska Miłość żadnemu jej dawać nie raczył, za którym by nie było mego świadectwa. Bo mnie każdemu łatwiejsza próba być może i kto będzie chciał profes[s]ionem fidei catholicae uczynić jakim umysłem, bo snać niektórzy dają się i z tym słyszeć, by też i przysiąc tylko, się do scizmy wrócić. Tak są dobrzy ludzie, że zgoła nie masz komu ufać. Lepiej jest poczekać, póki Pan Bóg kogo sczyrego pokaże, aniźli wilka do owczarnie Chrystusowej wpuścić, którego byśmy potem i dymem nie wykurzyli. A ja się też tymczasem będę starał o takiego, który by nie na zdradzie, ale szczyrze jedności Świętej był przychylnym,

70 d Lacuna, the missing letter added.

71 e Lacuna, one word missing.

72 f Lacuna, one word missing.

73 g Lacuna, the missing letter added.

$74{ }^{\mathrm{h}}$ Lacuna, the missing letters added.

75 i Lacuna, the probably missing word added.

76 j Lacuna, the missing letter added.

$77 \quad{ }^{\mathrm{k}}$ Lacuna, the probably missing letters added.

$78{ }^{1}$ Lacuna, the probably missing letters added.

$79{ }^{\mathrm{m}}$ Lacuna, the missing letters added.

$80{ }^{\mathrm{n}}$ Lacuna, one or two words missing.

81 'Lacuna, the word's ending missing.

82 P Lacuna, the word's beginning missing.

83 q Lacuna, several words missing.

$84{ }^{\mathrm{r}}$ Lacuna, the missing letters added. 
którego bych mógł bezpiecznie Waszej Królewskiej Miłości komendować. Co wszytko niech będzie przy woli i łasce Waszej Królewskiej Miłości.

Poddany i Bohomolca Waszej Królewskiej Miłości pop Dubieńskii szedł tam w potrzebach Kościoła swego prosić łaski Waszej Królewskiej Miłości, o czym sam da sprawę kancelaryi Waszej Królewskiej Miłości, za którym Majestatu Waszej Królewskiej Miłości pokornie proszę, aby mógł otrzymać to, o co prosi. Aby taką łaską Waszej Królewskiej Miłości i drudzy przywiedzieni, tym chętniejszy byli do jedności Świętej. Zatym z wiernym poddaństwem moim jako na[j]pokorniej całuję rękę Majestatu Waszej Królewskiej Miłości.

Datt z Chmielowa 1610bris Anno Domini 1603.

Naj[j]aśniejszego Majestatu Waszej Królewskiej Miłości wierny poddany sługa i Bogomolca Hypatius Metropolita

\section{Hipacy Pociej to King Sigismund III Vasa}

Różanka, March 2, 1604

Original, written by a secretary (the same who wrote the letters of April 22 and 29, 1602)

Library of the Polish Academy of Sciences in Kórnik, MS 1401, nr 43, p. 153

Naj[j]aśniejszy a Miłościwy Królu, Panie a Panie nasz Miłościwy Nie pomału mię to trapiło, iż po zejściu z tego świata władyki chełmskiego ta stolica bez pastyrza tak długo wakowała, a nie dziw, bo nie masz się na co kwapić, gdyż dobra kościelne wszytkie w ręku ludzi świeckich, o czymem do Waszej Królewskiej Miłości pierwej tego pisał. I otrzymałem list od Waszej Królewskiej Miłości do paniej Uchańskiej, wojewodziny bełskiej, ale jako baczę, nie chce prawa swego cedować, które słuszne li jest, sam Pan Bóg widzi. A Wasza Królewska Miłość jako pomazaniec Boży rozsądzić to możesz, bo jeśli żeśmy in schysmatae taką niełaską panów swych odnosili, że duchowne dobra osobam świeckim dawano, nic przy Kościele nie zostawiwszy, tedy in unione sancta, do którejeśmy dobrowolnie przystąpili, nie baczę, aby to rzecz była słuszna, żebyśmy

85 An unknown person. 
tejże niewoli zażywali. Co wszystko na łasce Waszej Królewskiej Miłości Pana naszego Miłościwego zależy mieć staranie o Kościele Bożym i o sługach jego.

Po te czasy najdowało się nieco takich, którzy chcieli łaski Waszej Królewskiej Miłości zażyć i o to władyctwo prosić, ale iż byli plaebei, a k temu scyzmą zarażeni, za żadnym z tych do Waszej Królewskiej pisać-em nie śmiał, bojąc się, abym miasto pastyrza wilka nie zalecił. Ale teraz był u mnie szlachcic uczciwy, pan Iwan Andrzejowski i deklarował się z tym, chcąc na stan duchowny wstąpić i Kościołowi Bożemu wiernie służyć, prosząc mię, abym do Waszej Królewskiej Mości pisał i za nim prosił, żebyś mu Wasza Królewska Mość z miłościwej łaski swej to władyctwo chełmskie dać raczył. Za którym i pan starosta chełmski, ${ }^{86} \mathrm{i}$ wiele zacnych ludzi szlachty chełmskiej wskazali do mnie, żądając, abym go promowował. Ja tedy, znając go z dawna być dobrym człowiekiem, a k temu jedności Swięntej przychylnym, chociaż nie literatem ${ }^{87}$ (o co u nas w Rusi barzo trudno), Waszej Królewskiej Miłości swego Miłościwego Pana za nim pokornie proszę, abyś mu Wasza Królewska Miłość to władyctwo dać raczył, który, tak rozumiem, będzie Kościołowi Bożemu pożyteczny i u ludzi przyjemny, i wzienty jako szlachcic uczciwy. Gdyż ta stolica od dawnego czasu na sobie szlachcica nie miała. Przeto też nie tylko u świeckich, ale u swoich duchownych w lekkim poważeniu byli, a teraz spodziewam się, że inaczej rzeczy pójdą, gdzie łaska Waszej Królewskiej Miłości przystąpi do tego. Ja też starać się o to będę, jakobym go za pomocą Bożą tak utwierdził i obwarował, żeby do scizmy ani pomyszlał, jakoż i sam jest alienus od tego.

Co wszystko łasce Waszej Królewskiej Miłości i miłościwemu baczeniu poruczam. A siebie i służby moje, i modlitwy kapłańskie z wiernym poddaństwem moim Majestatowi Waszej Królewskiej Miłości pokornie zalecam.

Dan z Rożanki Marca 2 d. Anno Domini 1604.

Naj[j]aśniejszego Majestatu Waszej Królewskiej Miłości wierny poddany sługa i Bogomolca Hypatius Metropolita totius Russiae manu propriae

86 Mikołaj Uhrowiecki.

87 What Pociej probably means is that the candidate for the bishopric lacks a suitable education. Andrzejowski possibly could not read or write well. 
8. Hipacy Pociej to King Sigismund III Vasa

Różanka, April 25, 1604

Original, written by a secretary (the same who wrote the letters of April 22 and 29, 1602 as well as March 2, 1604)

Library of the Polish Academy of Sciences in Kórnik, MS 1401, no. 45, pp. 161-62

Naj[j]aśniejszy a Miłościwy Królu, Panie a Panie nasz Miłościwy

$\mathrm{Z}$ wiernym poddaństwem moim służby i modlitwy moje kapłańskie zalecam Majestatowi Waszej Królewskiej Miłości.

List Waszej Królewskiej Miłości oddan mi jest, w którym mi Wasza Królewska Miłość pisać raczysz, obiecując dać władyctwo chełmskie za przyczyną moją szlachcicowi ziemie chełmskiej panu Iwanowi Andrzejowskiemu, tylkoż chcąc to mieć po mnie, abym dobrze uważywszy, jeśliby był tego godzien i jedności Świętej wiernie przychylny, abym do Waszej Królewskiej Miłości po wtóre za nim przez pisanie swe prośbę uczynił. Za co Waszej Królewskiej Miłości swemu Miłościwemu Panu pokornie dziękuję. Co samo jest wielkim świadectwem, iż Wasza Królewska Miłość na sprawy Kościoła Bożego jako król świętobliwy i katolicki łaskawe i pilne oko mieć raczysz, bo i na potem będzie to z pożytkiem Kościoła Bożego, kiedy scyzmatykowie nie będą śmieli uciekać się do Waszej Królewskiej Miłości o beneficja kościelne.

Co się tycze tego szlachcica, za którym-em pisał do Waszej Królewskiej Miłości, prosząc o władyctwo chełmskie, pewna rzecz, gdzie bym w czym najmniejszą wątpliwość baczył, nie śmiałbym do Waszej Królewskiej Miłości pisać, bo też to na sumnieniu moim należy postrzegać z pilnością tego, jakobym przyczyną swą wilka miasto pastyrza do Kościoła Bożego nie wprowadził. Dobrze tedy onego egzaminowawszy et sub iuramento upewnienie od niego otrzymawszy, widząc człowieka cnotliwego i barzo statecznego, pisałem do Waszej Królewskiej Miłości za nim. I teraz tedy ponawiam tej prośby mojej za nim do Waszej Królewskiej Miłości, któremu będzie li wola i łaska Waszej Królewskiej Miłości to dać, pewnie i przed poświąceniem, i przy poświąceniu onego starać się o to będę, jakobym iurament et professionem fidei catholicae wprzód z wielką pilnością obwarowawszy i ręczny zapis od niego otrzymawszy, na ten stan poświęcił.

Gdyż jeszcze żaden, za którym-em się przyczyniał do Waszej Królewskiej Miłości, Kościoła Bożego nie zdradził, chocaż był nieco począł 
władyka połocki ${ }^{88}$ jako stary pleść, ale gdym po niego pozwy wydał i degradacją, i ekskommunikacyją pogroził, ucichł i sprawował mi się [z] tego przez pisanie i pod przysięgą twierdząc, że tego nie winien. Władyka zaś piński, ${ }^{89}$ ten jako z dawna począł, dosyć swej powinności czyni. Daj Panie Boże, aby tacy wszyscy byli. Tylkoż nieboraka ubogiego ksiądz władyka łucki ${ }^{90}$ chce zsadzić z manastyra kobryńskiego jakimsi prawem od Waszej Królewskiej Miłości jemu danym, ${ }^{91}$ którego, jako za pierwszym władyką, tak i za tym nigdy nie używał. Ano godziłoby mu się i przydać, nie tylko co ująć, gdyż co więtsza część władyctwo turowskie podawania Waszej Królewskiej Miłości, które pospołu z wieków chodziło, odjęto jeszcze zmarłemu władyce $^{92}$ i temu nie chciano postąpić, co nieborak skromnie musi znosić do sczęśliwszego czasu, mając nadzieję o łasce Waszej Królewskiej Miłości, że Wasza Królewska Miłość i krzywdy Kościoła Bożego i zwierzchności swej pańskiej, jakoby ją kto iny nie władał, postrzec będziesz raczył. Gdyż my tu nie mamy królików żadnych, ale Waszą Królewską Miłość - jednego pomazańca Bożego - i za pana, i obrońcę, i podawcę najwyższego Kościołów Bożych ${ }^{93}$ i takich urzędów duchownych znamy.

Potrzeba też będzie listu Waszej Królewskiej Mości do władyki łuckiego i pińskiego, rozkazując im, aby się na konsekracją władyki nowego za oznajmieniem moim na miejsce pewne zjeżdżali. Bo ksiądz władyka łucki barzo cięszki na to mając, jakiś skrycie zajątrzony, umysł na mię, że też dosyć pobliżu mieszkając ledwie mil cztery ode mnie, na żadne sprawy Kościoła Bożego zjeżdżać nie chce, niedostatkiem i ubóstwem wymawiając się, choca sowito wienczy [ma], aniżeli ja i na metropolią i na władyctwo trzymam. O którym pisałbym i co więncej, ale nie chcę Waszą Królewską Miłość tym turbować. Zgoła daj Panie Boże, aby się w powinności swej lepiej poczuwał. A iż zgoła pogardza jurysdycyją moją metropolią, zdało mi się za rzecz słuszną Waszej Królewskiej Miłości tę kilka słów napisać i to tak secrete, żeby potym nieprzyjacielom Kościoła Bożego nie dać ansy do pośmiewiska, że nas trocha i to się nie zgadzamy.

88 Gedeon Brolnicki, the Uniate bishop of Połock in 1601-18.

89 Paisjusz Hipolitowcz Sachowski, the Uniate bishop of Pińsk-Turów in 1603-26.

90 Cyryl Terlecki, bishop of Lutsk-Ostrog in 1585-1607, since 1596 as an Uniate bishop.

91 Terlecki was appointed by Sigismund III on May 30, 1596 as the Kobryń archimandrite (cf. $A Z R$, vol. 4, no. 96, p. 133).

92 Jona Hohol, bishop of Turow-Pińsk in 1596-1602.

93 Here: probably the Uniate and Catholic churches. 
Ostatek łasce Majestatu Waszej Królewskiej Miłości poruczam i jako wierny poddany a Bohomolca Waszej Królewskiej Miłości ze wszeliaką pokorą rękę Waszej Królewskiej Miłości Pana swego Miłościwego całuję.

Dan z Rożanki 25 Aprilis Anno Domini 1604. Naj[j]aśniejszego Majestatu Waszej Królewskiej Miłości wierny poddany stuga i Bogomolca Hypatius Archiepiscopus Metropolita Kioviensis

\section{Hipacy Pociej to Lew Sapieha}

'from a tavern, in travel', November 9, 1611

Original (autograph), paper damaged

Centralnyj dierżawnyj istoricznyj archiw Ukrajiny (Kiev), f48, op. 1, MS 478

Miłościwy Panie Kanclierzu Panie mój Miłościwy Proszę swego Miłościwego Pana uniżenie, żebyś mi Wasz Mość przez sługę mego pana Dachnowica przysłać raczył te przywileje obadwa, tak na koadiutorię ${ }^{94}$ jako i pana Mor $\left[\mathrm{o}^{95 \mathrm{~s}}\right]$ chowskiego $^{96}$ cessi $\mathrm{m}\left[\mathrm{o}^{97 \mathrm{t}}\right]$ jej na tę wioskę. Tylko o to pilnie proszę, żeby to było rotulo oc[c]luso, żeby o tym żaden nie wiedział, gdyż nie mieszkając, wyjeżdżam do Litwy tro[szkę?98u] [ty ${ }^{99 v}$ ] lko doma koniam odpoczynąw [szy $\left.{ }^{100 \mathrm{w}}\right]$.

Listy do Ojca Świętego odeślę księdzu legatowi ${ }^{101}$ cum summa commendatione osoby Wasz Mości mego Miłościwego Pana i takiego dobrodziejstwa, któreśmy po panu Bogu a Jego Królewskiej Miłości wiencej, aniźli

94 The charter appointing Józef Welamin Rutski as the Coadjutor bishop of Kiev. According to it, he became after Pociej's death the head of the Uniate church and he remained in office between 1613-37.

$95 \mathrm{~s}$ The fragment torn out, the missing letter added.

96 Eliasz (monastic name: Joachim) Morochowski - the secretary of the Metropoloitan Pociej, his 'right hand, and sice 1609 also the royal secretary. After Pociej's death, he became the bishop of Volodymyr-Brest (1613-1631).

$97 \mathrm{t}$ A fragment of paper destroyed, the missing letter added.

$98 \mathrm{u}$ The fragment torn out, probably missing letters added.

99 v Lacuna, the missing letters added.

100 w Lacuna, the missing letters added.

101 Probably the papal nuncio Francisco Simonetta, whose mission to Poland was closing to the end at that time. 
powinniśmy? $\left.{ }^{102 x}\right]$, po Wasz Mości doznali. Mam za to, że to w[dzięcz $\left.{ }^{103 y}\right]$ nie przy[j]mie.

Zatym Wasz Mość Panu Bogu w Jego Świętą opiekę poruczam, a samego siebie i służby moje z modlitwami ustawicznemi łasce Wasz Mości swego Miłościwego Pana pilnie zaliecam.

Dan z gospody na wyjeździe 9 9bris Anno Domini 1611.

Wasz Mości swego Miłościwego Pana

$\mathrm{Na}[\mathrm{j}]$ niższy Sługa, Bogomodlca

Mitropolit Hypathius

[postscript:] Co by też było potrzeba z Metryki, proszę swego Miłościwego Pana, aby synowi memu było wydano do rąk tegoż pana Dachnowica, służebnika mego.

\section{Hipacy Pociej to Lew Sapieha}

Nowogródek, December 27, 1611

Original (autograph)

Centralnyj dierżawnyj istoricznyj archiw Ukrajiny (Kiev), f. 48, op. 1, MS 484

Jaśnie Wielmożny Panie Kanclierzu, Panie i dobrodzieju mój Miłościwy Służby i modlitwy moje zwykłe do łaski Wasz Mości mego Miłościwego Pana pilnie zalecam.

Rozumiejąc o tym, iż Wasz Mość mój Miłościwy Pan z Warszawy do domu wrócić się raczył, powinność moja była (zwłaszcza tu pobliżu będąc) tym pisaniem służby na[j]niższe oddawszy, dobre zdrowie Wasz Mości mego Miłościwego Pana nawiedzić, w którym aby Wasz Mość Pan Bóg Wszechmogący długo przy szczęśliwym panowaniu chować raczył, uprzejmym sercem życzę i onego proszę. A zwłaszcza, aby ten żal i frasunek ${ }^{104}$ Wasz Mości, w którym tak mieć dom wszytek Wasz Mość mego Miłościwego Pana chciał, powodzeniem pomyślnym nagrodzić

$102 \mathrm{x}$ Lacuna, the probably missing letters added.

103 y Lacuna, the probably missing letters added.

104 Pociej alludes here to Sapieha mourning his second wife, Elżbieta née Radziwiłł, who died in 1611 . 
raczył. Przy tym też Wasz Mość mego Miłościwego Pana proszę, abym mógł mieć jaką wiadomość strony przywilejów ${ }^{105}$, którem za łaską Jego Królewskiej Mości, a osobliwą przyczyną Wasz Mości mego Miłościwego Pana otrzymać miał, według onych kopii, którem był przy Wasz Mości moim Miłościwym Panie i dobrodzieju zostawił. Dzierżę to o nieodmiennej łasce Wasz Mości mego Miłościwego pana przeciwko sobie, iż mię w tym Wasz Mość przebaczyć nie raczył i wiadomego uczynić nie zaniechasz.

Do którego się łaski i powtóre z niegodnemi modlitwami memi oddawam.

Z Nowogródka 27 10bris 1611. Wasz Mości mego Miłościwego Pana $\mathrm{Na}[\mathrm{j}]$ niższy służebnik i Bogomolca Hypathius Archiepiscop Metropolit Kiowsky Halicky i wszystkiej Rusi ręką własną

\section{Hipacy Pociej to Lew Sapieha}

Vilnius, June 17, 1612

Original (written by a secretary)

Centralnyj dierżawnyj istoricznyj archiw Ukrajiny (Kiev), f48, op. 1, MS 499

Jaśnie Wielmożny a Miłościwy Panie Kanclierzu, Panie mój Miłościwy Służby moje zaliecam łasce Wasz Mości.

W bractwie naliwajkowskim ${ }^{106}$ rzadko bez nowin, a nigdy pewnych, jakoż ówdzie udali za rzecz prawdziwą jakoby Poroszko ${ }^{107}$ w Słucku na pogrzebie Księżny Jej Mości ${ }^{108}$ miał Wasz Mości witać i uskarżać się na niełaskę Wasz Mości na ono wspominanie osoby jego na sejmie. Jakobyś mu Wasz Mość na to miał powiedzieć, że ja ciebie mam za dobrego człowieka, alie mi ciebie mitropolit i ociec Rutsky, przyszed[ł]szy do mnie z jezuitami, tak udali i żałuję tego teraz na koniec; jakobyś Wasz Mość

105 See the previous letter.

106 An Orthodox brotherhood that functioned in Vilnius, at the church of Holy Spirit.

107 Iwan Poroszko, one of the most active members of the brotherhood of Holy Spirit, in 1597 accused wrongfully by Sapieha of spying for Moscow; he found shelter at the Radziwiłł court in Birże - see above.

108 The funeral of the wife of Janusz Radziwiłt, Zofia née Olelkowicz, princess of Słuck. 
miał tak mówić, że mi już ta unia przemierzła i co wiencej egzagerując na mię, czemu ja nie wierzę, aby to z ust Wasz Mości zacnych i świętobliwych wychodzić miało, bo też i ja nie pamiętam, żebym do Wasz Mości mego Miłościwego Pana z takimi nowinami miał przychodzić. Alie tym niebożnym ludziom nie nowina, takie pliotki rozsiewać między liudzie, których iż nie mogą [pra ${ }^{109}$ ] wdą (bo jej nie maja) przy sobie zatrzymać, muszą, jako zwykli, kłamstwem narabiać. Jakoż i o konstytucjach sejmowych inaczej udali, aniżeli stanęły.

Alie nie jedno, bo i też w Wilnie w żywe oczy takie nowiny o patriarsze moskiewskim $^{110}$ rozsiali, czego i w pomyszle mu nie było, czym teraz Wasz Mości mego Miłościwego Pana zabawiać nie chcę. Dowiesz się Wasz Mość, gdy, da Pan Bóg, przyjachać będziesz raczył do Wilna. A ja na ten czas służby moje najniższe łasce Wasz Mości swego Miłościwego Pana zaliecam. Dan z Wilna Anno Domini 1612 Junii 17 d.

Wasz Mości swego Miłościwego Pana $\mathrm{Na}$ [j]niższy Służebnik i Bogomolca Mitropolit K[ijowski]

\section{APPENDIX}

Cyryl Terlecki, Metropolitan of Lutsko-Ostrog, to King Sigimund III Vasa Rożyszcze, December 20, 1603

Original (autograph)

Library of the Polish Academy of Sciences in Kórnik, MS 1402, no. 41, p. 170

Naj[j]aśniejszy Miłoscziwy Królu, Panie, Panie mnie Miłościwy Uniżone służby i modlitwy moje kapłańskie i wiernoscz poddaństwa mego Majestatowi Waszej Królewskiej Mości oddawam.

$109 \mathrm{z}$ Lacuna, the missing letters added.

110 Patriarch Ignatius, who stayed early in 1612 in Vilnius, who resided in the Uniate monastery of the Holy Trinity; eventually, he accepted the union. Ignatius was the Patriarch of Moscow under False Dmitriy I (1605-06), and then after the capture of Moscow by the hetman Stanisław Żółkiewski in August 1610. Pociej mentioned the Patriarch's arrival and his stay in Vilnius in two letters to Lew Sapieha. See: H. Pociej to L. Sapieha, March 26 and April 9, 1612 (both sent from Vilnius), in L. Timoszenko, 'Dwa listy Ipatija Potija do Lewa Sapiehy', Kijiws'ka Starowina, 2002, no. 1/343, pp. 103-13. 
Naj[j]aśniejszy Miłościwy Królu, nie radbym nigdy Majestatu Waszej Królewskiej Mosczy Panu swemu Miłościwemu dokukę [s] i nabieganie czynił, alie biedy, kriwdy i gwałt Cerkwie Bożej wyciska to na mnie, że się muszę do Pana Boga Wszechmogącego i do Waszej Królewskiej Mosczy

Pana swego uciekać o obronę Cerkwie Bożej i żałosną kriwdę, i szkodę Cerkwie Bożej, i obelżenie moje Bogomodlce Waszej Królewskiej Mosczy. Donoszę i uskarżam Majestatowi Waszoje Królewskiej Mości na pana Mikołaja Siemaszka, starostę łuckiego, który to pan starosta w miasto obrony mnie i Cerkwie Bożej, żeby od inszych nieprzyjaciół Cerkwie Bożej miał bronić, tu sam kriwdzi. Naprzód Majestatowi Waszej Królewskiej Mości opowiadam, isz majętnosczy leżące cerkiewne, Stawek i Trojeczsczyznę, poodymował, a potem konwent i mieszkanie moje, i kapituły mojej przy cerkwie Bożej w zamku łuczkim zgwałcił, budowanie mieszkania mego porąbał, porozrucał i w pieczach ku wzgardzie Cerkwie Bożej popalić kazał, o który gwałt i o spliądrowanie tego konwentu pozwałem go z urzędu jego starościńskiego przed sąd Waszej Królewskiej Mosczy. A isz my wszysczy osoby duchowne po Panu Bogu do Waszej Królewskiej Mosczy naszego Miłościwego Pana uciekać [się] powinni, uniżone [s] proszę Majestatu Waszej Królewskiej Mości Pana mego Miłościwego o sprawiedliwoscz z niego, aby Cerkiew Boża jako i mieszkanie moje z kapitułą moją, Bogomodlców Waszej Królewskiej Mosczy, wiecznie uspokoić raczył. Pan Bóg Waszej Królewskiej Mosczy wieczną zapłatą będzie. A ja sam ze wszytkim duchowieństwem moim we dnie i w nocy Pana Boga Wszechmogącego za dobre zdrowie Waszej Królewskiej Mosczy Pana mego Miłościwego prosić winien jestem, przy czym i powtorze modlitwy moje i wierne poddaństwo Waszej Królewskiej Mosczy oddawam.

Z Roziscz dnia 20 Decembra Roku 1603. Waszej Królewskiej Mosczy Pana Pana Mego Miłoscziwego ustawiczny Bogomodlca i wierny poddany Kiril Terleczky, Bożą miłością episzkop luczky i ostrogsky 